\title{
Essay
}

\section{Minorities, Shareholder and Otherwise}

\author{
Anupam Chander ${ }^{\dagger}$
}

\section{INTRODUCTION}

Corporate law understands what constitutional law does not. Minority status matters to law. Where today's constitutional jurisprudence of equal protection aspires to colorblindness, corporate law places minority concerns at the heart of its endeavor. The minorities of corporate law are minority shareholders-investors holding small, noncontrolling interests in the corporation. Law's solicitude, it seems, is limited to minority shareholders, not minority races. Where constitutional law sees only one race"American" - corporate law recognizes minority status as a central datum for legal decision. At the same time that constitutional law moves to limit

$\dagger$ Professor of Law, University of California, Davis, School of Law; Visiting Professor, Cornell Law School. A.B. 1989, Harvard University; J.D. 1992, Yale University. E-mail: anupam@post.harvard.edu. I profited much from presentations to the law faculties at the University of California, Davis and Loyola University of Los Angeles. I am also indebted to the law faculty at Syracuse University, where I presented this paper as Endries Lecturer in honor of Dean Hannah Arterian. Thanks to Jack Ayer, Boris Bershteyn, Scott Cummings, Chris Elmendorf, Martha Ertman, Eric Fleisig-Greene, Jeff Gordon, Janet Halley, Larry Helfer, Bob Hillman, Kevin Johnson, Tom Joo, Prasad Krishnamurthy, Margaret Jane Radin, Keith Sealing, and Tobias Wolff for helpful conversations and comments. Thanks also to Sahar Kianfar, Heather Rowan, and the wonderful law librarians at King Hall for very able research assistance. Thanks also to Rex Perschbacher for his generous support throughout this writing. I am especially grateful to Madhavi Sunder for her courage and determination, which serve as constant inspiration. I dedicate this to Harish and Anoushka.

1. Adarand Constructors, Inc. v. Pena, 515 U.S. 200, 239 (1995) (Scalia, J., concurring in part and concurring in the judgment) ("In the eyes of government, we are just one race here. It is American."). 
affirmative action for racial minorities and women, ${ }^{2}$ corporate law embraces affirmative action for minority shareholders. ${ }^{3}$

This Essay examines how two different areas of the law have solved the question-perhaps the "problem"4 —of minorities. In so doing, it seeks to uncover the underlying dynamics of life as a "minority," abstracted from the context of the corporation and the constitutional realm. By contrasting corporate and constitutional law, this Essay begins to conceptualize "minority" status as a legal fact.

Being a member of a minority race is certainly different from being a minority investor in a corporation. The history of race is inflected with violence and struggle unparalleled in corporate disputes. But legal scholars have yet to ask the key question: Do the differences between race and shareholding justify the radically different approaches to minority status adopted by corporate and constitutional law? Even more crucially, do the differences between the two justify a greater solicitude for minority investors than for minority races? I consider possible differences-namely, history, a special concern for property rights, the possibility of exit in a liquid capital market, and the amorphousness of racial discrimination. I conclude that these differences should lead us to seek a reversal in legal priorities-stronger protection for minority races than for minority investors.

The central distinction between the two legal approaches to minorities can be summarized efficiently as follows: Constitutional law believes that equality requires blinding oneself to minority status. Corporate law, to the contrary, believes that equal treatment can only be assured by taking minority status into account. For corporate law, equality is not sameness.

This Essay responds to the recent "demoralization of the egalitarian project." I demonstrate how the egalitarian spirit is alive and well-but in the materialistic world of capital. The current "assault on egalitarianism"6 confines itself to seeking to dismantle programs protecting women and

2. See infra notes $282-293$ and accompanying text.

3. I use the term "affirmative action" in the strongest sense identified by William Van Alstyne-as minority-mindfulness in decisionmaking resulting in either a preference or a disproportionate distribution of benefits. See William W. Van Alstyne, Affirmative Actions, 46 WAYNE L. REV. 1517, 1536 (2000).

4. W.E.B. DU BoIS, THE SOULS OF BlaCK FolK 1-2 (Modern Library 1996) (1903) (reporting a query put to African Americans: "How does it feel to be a problem?").

5. Kenneth Arrow et al., Introduction to MERITOCRACY AND ECONOMIC INEQUALITY, at ix, ix (Kenneth Arrow et al. eds., 2000). In other work, I have sought to revive the egalitarian project in a number of domains. See Anupam Chander, Diaspora Bonds, 76 N.Y.U. L. REV. 1005, 1012 (2001) [hereinafter Chander, Diaspora Bonds] (discussing an innovative method of raising capital for developing nations); Anupam Chander, The New, New Property, 81 TEX. L. REV. 715, 718-19 (2003) (arguing that cyberlaw scholarship has focused on liberty values to the exclusion of equality values); Anupam Chander, Whose Republic?, 69 U. CHI. L. REV. 1479, 1493-97 (2002) (book review) (describing the egalitarian possibilities of the Internet).

6. Arrow et al., supra note 5 , at xi. 
people of minority races and leaves undisturbed the elaborate legal structure that protects minority shareholders. This assault is best seen in the Supreme Court's 1995 decision in Adarand Constructors, Inc. v. Pena. ${ }^{7}$ In that case, the Court subjected a preference for minority subcontractors to strict scrutiny, thereby requiring any affirmative action program in favor of people belonging to minority races to be both justified by a compelling state interest and narrowly tailored to further that interest. The fact that the racebased classification was motivated by benign, perhaps even noble, motives did not itself salvage the use of race. ${ }^{8}$ The recent Term's decisions in Grutter v. Bollinger ${ }^{9}$ and Gratz v. Bollinger ${ }^{10}$ confirm that governmental race consciousness can survive strict scrutiny, yet seem far from embracing egalitarianism in either rhetoric or substance.

Constitutional law views discrimination against the majority with the same distaste as discrimination against the minority-requiring strict scrutiny in either case. Corporate law, on the other hand, routinely intrudes into the corporation to secure the protection of minority shareholders against controlling persons within corporations.

A simple thought experiment illustrates my inquiry. Imagine if we ran a corporation using the rules of constitutional law. Decisions would be rendered by majority rule of the shareholders (who become "citizens" of the corporation). This would not mean that the majority could do whatever it wanted. A constitutional charter, devised at the corporation's founding, would limit possible actions. Indeed, there would be a guarantee of "equal protection." But, as I show, this guarantee would be substantially less protective or demanding than the special duties that corporate law imposes on the board of the corporation and on any controlling shareholder vis-à-vis minority shareholders. The governors of the corporation would have no special duty to ensure that the benefits of their actions did not disproportionately redound to majority investors. There would be no ongoing obligation of fair treatment of the minority or duty to work on the

7. 515 U.S. 200 (1995). The United States is not alone in its retreat from affirmative action. The year the Court handed down Adarand, the European Court of Justice ruled that a German law preferring equally-qualified women over men in occupations in which women were underrepresented violated a 1976 European Council Directive mandating equal treatment of men and women. Case C-450/93, Kalanke v. Freie Hansestadt Bremen, 1995 E.C.R. I-3051, [1995] 1 C.M.L.R. 175 (1995). Some countries, however, enshrine affirmative action in their constitutions. See, e.g., CAN. CONST. (Constitution Act, 1982) pt. I (Canadian Charter of Rights and Freedoms), $\S 15(2)$ (permitting the government to carry out any "law, program or activity that has as its object the amelioration of conditions of disadvantaged individuals or groups"); INDIA CONST. art. $15, \S 3$ ("Nothing in this article [prohibiting state discrimination] shall prevent the State from making any special provision for women and children .... [or for] any socially and educationally backward classes ...."); see also Martha C. Nussbaum, Sex, Laws, and Inequality: What India Can Teach the United States, DAEDALUS, Winter 2002, at 95.

8. 515 U.S. at 227-29.

9. 123 S. Ct. 2325 (2003).

10. 123 S. Ct. 2411 (2003). 
minority's behalf. There would be no duty of loyalty that would prevent the board of directors and the controlling shareholders from exploiting their power for personal profit at the expense of the minority.

The converse experiment is equally illuminating. Imagine if we ran the government using the rules of corporate law. Decisions would be rendered by majority rule, but there would be special protections ensuring that the process would be fair. On occasion, there might even be such strict procedures as cumulative voting, ${ }^{11}$ which would give minorities a presence in the governing legislature (including the nearly whites-only Senate).$^{12}$ But minorities would receive not only procedural rights, but also substantive rights. Minority citizens would be able to bring a cause of action for "oppression" when faced with inequitable distributions of social resources. Most importantly, they would find various legal doctrines-including derivative suits, freeze-out claims, and fiduciary obligations-that would seek to ensure their equitable treatment with respect to any transactions undertaken by the government.

But to say that corporate law approaches minority concerns in the manner described does not establish that constitutional law should adopt a similar approach, mutatis mutandis. That is not the goal of this endeavor. Nor is the goal to suggest that constitutional law should borrow mechanisms for minority protections from corporate law. Rather, it is to force a reexamination of constitutional law's great hesitancy to view information regarding minority status as crucial to administering justice.

At the same time, my goal is to reinterpret corporate law. Values of fairness and equality turn up in the sharp-elbowed world of business, exactly where we might least expect to find them. Despite scholarly commentary to the contrary, the watchwords of corporate law include not only wealth maximization, but also fairness. Oppression is a cause of action found not in constitutional law, but in corporate law. Indeed, I show that much of corporate law can be explained as protective of minority shareholders. This explanation sheds light on the mystery of what corporate law is about. Contrary to the law and economics meta-narrative popular

11. Lani Guinier's proposal in this regard earned her the (mis)label "Quota Queen." See Clint Bolick, Editorial, Clinton's Quota Queens, Wall ST. J., Apr. 30, 1993, at A12. For Guinier's own work on the subject, see Lani Guinier, Groups, Representation, and Race-Conscious Districting: A Case of the Emperor's Clothes, 71 TEX. L. REV. 1589 (1993); Lani Guinier, More Democracy, 1995 U. CHI. LEGALL F. 1; Lani Guinier, No Two Seats: The Elusive Quest for Political Equality, 77 VA. L. REV. 1413 (1991) [hereinafter Guinier, No Two Seats]; and Lani Guinier, The Triumph of Tokenism: The Voting Rights Act and the Theory of Black Electoral Success, 89 MICH. L. REV. 1077 (1991) [hereinafter Guinier, The Triumph of Tokenism].

12. There are currently three nonwhite members of the United States Senate, two of them from the majority-minority state of Hawaii. See Minorities in the Senate, at $\mathrm{http} / / / \mathrm{www}$.senate.gov/artandhistory/history/common/briefing/minority_senators.htm (last visited Aug. 30, 2003) (listing all fifteen minority members who have served during the history of the Senate). 
today, ${ }^{13}$ the shareholder wealth-maximization norm does not suffice as a complete specification of corporate law. I show that corporate law is sensitive not only to wealth maximization, but also to wealth distribution.

Rather than leave minority shareholders to the ruthless efficiency of the marketplace, corporate law steps in to provide mandatory and default protections for such shareholders. Corporate law's concern for minorities is evident in its elaborate framework protecting minority interests in the corporation. The vital mandatory core of corporate law ${ }^{14}$ shows that the contractarian victory is incomplete. Even contractarians Easterbrook and Fischel, in their classic economic explanation of corporate law, find room for mandatory legal protections for minority capitalists. ${ }^{15}$ Contractarians might have preferred to leave investors to negotiate protections for themselves, with investors denying corporations capital unless sufficient contractual safeguards were in place. But this is not the approach of current corporate law. In fact, minority investors need not rely entirely on their own well-struck bargains to protect themselves from unfair exploitation by dominant shareholders or self-dealing management. ${ }^{16}$

Minority shareholder protection is a central part of the corporate governance model that American scholars seek to export to transitional and developing economies. ${ }^{17}$ Indeed, one of the most famous claims in the field of comparative corporate governance is that the protection of minority investors-both minority shareholders and outside creditors-offers the "legal DNA of good economies." 18 According to this claim, minority

13. See, e.g., Mark J. Roe, The Shareholder Wealth Maximization Norm and Industrial Organization, 149 U. PA. L. REV. 2063, 2065 (2001) ("Shareholder wealth maximization is usually accepted as the appropriate goal of American business circles."). See generally Lynn A. Stout, Bad and Not-So-Bad Arguments for Shareholder Primacy, 75 S. CAL. L. REV. 1189 (2002) (assessing arguments for the shareholder wealth-maximization norm).

14. For an authoritative definition of this core, see John C. Coffee, Jr., The Mandatory/Enabling Balance in Corporate Law: An Essay on the Judicial Role, 89 COLUM. L. REV. 1618 (1989).

15. See Frank H. Easterbrook \& Daniel R. Fischel, THE ECONOMIC STRUCTURE of CORPORATE LAW 22-35 (1991) (describing reasons for trumping corporate contracts).

16. This does not mean that minority shareholders can be complacent. See Park McGinty, The Twilight of Fiduciary Duties: On the Need for Shareholder Self-Help in an Age of Formalistic Proceduralism, 46 EMORY L.J. 163, 170-80 (1997); see also Nixon v. Blackwell, 626 A.2d 1366, 1380 (Del. 1993) (en banc) ("It would do violence to normal corporate practice and our corporation law to fashion an ad hoc ruling which would result in a court-imposed stockholder buy-out for which the parties had not contracted."); Zidell v. Zidell, Inc., 560 P.2d 1091 (Or. 1977) (declining to enjoin a sale of corporate stock where the minority investor had failed to protect himself by contract).

17. For example, we are told that Russia has failed recently both in ensuring minority shareholder protection and in creating a culture of respect for the rule of law. See, e.g., Bernard Black et al., Russian Privatization and Corporate Governance: What Went Wrong?, 52 STAN. L. REV. 1731 (2000).

18. Rafael La Porta et al., Investor Protection and Corporate Governance, 58 J. FIN. ECON. 3, $4(2000)$ ("Corporate governance is, to a large extent, a set of mechanisms through which outside investors protect themselves against expropriation by the insiders."); see also David Wessel, The Legal DNA of Good Economies, WALL ST. J., Sept. 6, 2001, at 1 (further describing the La Porta 
investor protection is one of the keys to the American success story ${ }^{19}$ and is the future of corporate law worldwide. ${ }^{20}$

This Essay proceeds as follows. In Part I, I reread the canon of corporate law. While the economic reading of corporate law doctrines finds in them a concern for efficiency, my review reveals a simultaneous commitment to minority protection and egalitarianism. I identify a theory of power that underlies much of corporate law and that speaks to constitutional debates. I suggest that corporate law is more than a device "to reduce the transaction costs of private bargaining by providing a code of standard legal arrangements." ${ }^{21}$ As crafted over the centuries by judges and legislators, corporate law is also a device to ensure that minorities will be treated fairly, even without a.showing that they would have bargained for contractual safeguards in the absence of transaction costs. Although contractarian scholars have recently advocated lifting such protections, the Enron and WorldCom debacles have begun to turn the tide toward stronger, not weaker, protection. ${ }^{22}$

Part II considers whether the analogy between minority shareholders and minority races holds. I move from the question in Part I-what does corporate law do? - to the question, why does it do it? I argue that the justifications for corporate law's active intercession on behalf of minorities also pertain to the constitutional realms of education and employment. I locate corporate law's concern for minorities in a desire to promote capital formation as well as to ensure fairness. These goals should also animate our constitutional jurisprudence. "But race and shareholding are different!" many will protest. Accordingly, I consider the claim that differences between the two classes of minorities justify the different approaches taken toward them. I then examine what corporate law might teach us about how to define the classes of minorities relevant to legal decisionmaking.

Part III applies the theoretical arguments offered in the paper to three contemporary civil rights debates centered on affirmative action. I consider first the question of affirmative action in higher education, an issue recently

research). Their claim is not without controversy. See John C. Coffee, Jr., The Future as History: The Prospects for Global Convergence in Corporate Governance and Its Implications, 93 Nw. U. L. REV. 641, 653 (1999) (identifying the constraints on convergence in corporate governance).

19. See La Porta et al., supra note 18, at 18-22; Rafael La Porta et al., Law and Finance, 106 J. POL. ECON. 1113, 1127-33 (1998).

20. See John C. Coffee, Jr., Racing Towards the Top?: The Impact of Cross-Listings and Stock Market Competition on International Corporate Governance, 102 COLUM. L. REV. 1757, 1761 (2002).

21. RALPH K. WINTER, GOVERNMENT AND THE CORPORATION 1 (1978).

22. See, e.g., Sarbanes-Oxley Act of 2002, Pub. L. No. 107-204, 116 Stat. 745 (to be codified in scattered sections of $11,15,18,28$, and 29 U.S.C.); Small v. Fritz Cos., 65 P.3d 1255, 1263 (Cal. 2003) (observing that "[t]o open the newspaper today is to receive a daily dose of scandal, from Adelphia to Enron and beyond" and permitting a state law action for securities fraud where the shareholder held stock in reliance on the defendant's misrepresentations (citation and internal quotation marks omitted)). 
addressed by the Supreme Court in Grutter and Gratz. ${ }^{23}$ Drawing upon theoretical and empirical literature on the economics of discrimination, I show that the reasons why law protects minority shareholders are also the reasons why law should sometimes promote affirmative action for minority races. Next, I analyze a new state constitutional initiative in Californiabeing put to a vote as this publication goes to press-that promises to be as divisive as Proposition 209. This new initiative, which I call the "Racial Blindness Initiative," 24 would prevent the government from collecting information about race, thus carrying the concept of colorblindness to its logical conclusion. Finally, I preview the coming demographic shiftalready reality in California - that will make minority races a majority of the population. The advent of this majority-minority configuration will lead many to question the need for affirmative action.

\section{REREADING THE CANON}

Consider the canonical case of Dodge v. Ford Motor Co., ${ }^{25}$ which has been interpreted as a classic statement of the norm of wealth maximization. $^{26}$ Exercising absolute control over the company he founded, ${ }^{27}$ Henry Ford refused to increase the stockholders' dividends, preferring instead to reinvest the capital in the business. The Dodge brothers, then shareholders in Ford Motor, were piqued by his refusal to issue a dividend and sued. While the court declined to interfere with the proposed expansion, it held that Henry Ford's professed desire to benefit the public violated his obligation to his shareholders. ${ }^{28}$

The case has come to stand for the proposition that directors must manage a corporation so as to maximize the wealth of shareholders. ${ }^{29} \mathrm{But}$ this seems an odd reading given that Henry Ford himself was the largest shareholder of the Ford Motor Company, with over half of the company's

23. Gratz v. Bollinger, 123 S. Ct. 2411 (2003); Grutter v. Bollinger, 123 S. Ct. 2325 (2003).

24. While described by its proponents as a "Racial Privacy Initiative," the initiative does little to protect privacy - after all, governmental forms inquiring about racial information often permit the individual to refuse to divulge such information, so someone desiring to protect her privacy can generally do so now. The initiative is better characterized as a blindness proposition because it forces governmental ignorance of racial information.

25. 170 N.W. 668 (Mich. 1919).

26. Shareholder wealth maximization remains corporate law's norm, at least in principle. See Stephen M. Bainbridge, In Defense of the Shareholder Wealth Maximization Norm: A Reply to Professor Green, 50 WASH. \& LEE L. REV. 1423, 1423-24 (1993) (observing that "the mainstream of corporate law remains committed to the principles espoused by the Dodge court"). But cf. D. Gordon Smith, The Shareholder Primacy Norm, 23 J. CORP. L. 277 (1998) (arguing that the shareholder primacy norm has little effect on corporate decisionmaking).

27. 170 N.W. at 671 (noting that the "policy of the board of directors has been dominated and controlled absolutely by Henry Ford").

28. Id. at 684-85.

29. See, e.g., Robert Charles Clark, Corporate LaW $\S 16.2$, at 678-79 (1986). 
stock in his name. ${ }^{30}$ The court did not worry that Henry Ford was not maximizing his personal earnings. Rather, its concern was with Henry Ford's minority co-owners; any effect on Henry Ford's own finances was incidental. The court held not that insiders must simply maximize shareholder wealth, but that they must do so equitably. ${ }^{31}$ The court made its underlying concern for minority shareholders quite plain: "There should be no confusion (of which there is evidence) of the duties which Mr. Ford conceives that he and the stockholders owe to the general public and the duties which in law he and his codirectors owe to protesting, minority stockholders." 32

Indeed, as this Part demonstrates, minority shareholder protection is at the heart of the corporate law enterprise. I do not offer this as a new observation. Adolf Berle, Jr. recognized it half a century ago: The rules of corporate law, he wrote, "were and still are directed primarily toward the protection of the property interests of minority stockholders." ${ }^{\text {"33 }}$ But despite its long provenance, this fundamental value has often been obscured by the focus on shareholder wealth maximization-a focus that omits the special attention that corporate law pays to a certain type of shareholder.

While there is a strong majoritarian character to corporate law, ${ }^{34}$ that should not obscure the affirmative steps that corporate law takes to protect minority shareholders. The key distinction is that, while majoritarian devices in corporate governance require nonintervention on the part of

30. The court described Henry Ford as "the president of the company, who owns and for several years has owned 58 per cent. of the entire capital stock of the company." Dodge, 170 N.W. at 671 .

31. The concern for equitable distribution can be understood as purely instrumental to the goal of wealth maximization, because inequities in distribution might impact the ability of corporations to raise capital in the future. See infra Subsection II.B.2. One scholar has suggested that corporate law is indifferent to distributional issues among asset classes in the corporation. See Thomas A. Smith, The Efficient Norm for Corporate Law: A Neotraditional Interpretation of Fiduciary Duty, 98 MICH. L. REV. 214, 248-57 (1999). Smith's argument focuses, however, not on distributional issues among shareholders, but on distributional issues between shareholders and bondholders. Therefore, his claim is generally inapposite to mine. Even between shareholders and bondholders, however, the Delaware Supreme Court had previously given Revlon's noteholders short shrift in favor of the company's equityholders, thus undermining Smith's claim. See Revlon, Inc. v. MacAndrews \& Forbes Holdings Inc., 506 A.2d 173 (Del. 1986). Smith does note that courts have sanctioned recapitalizations that favor common stockholders over preferred stockholders, Smith, supra, at 255-56, but any preference given to common stockholders seems consistent with my claim that courts are especially concerned with the lot of minority shareholders.

32. Dodge, 170 N.W. at 684 (emphasis added). This sentence is omitted from the usual citations to the case, which only quote the sentence that immediately follows this one: "A business corporation is organized and carried on primarily for the profit of the stockholders." Id.

33. Adolf A. Berle, Jr., "Control" in Corporate Law, 58 CoLUM. L. REV. 1212, 1212 (1958).

34. The American Law Institute has gone so far as to characterize American corporate law as a "largely unqualified system of majoritarian control." 2 PRINCIPLES OF CORPORATE GOVERNANCE: ANALYSIS \& RECOMMENDATIONS pt. 7, ch. 4 introductory note (1994) [hereinafter PRINCIPLES OF CORPORATE GOVERNANCE]. Yet the ALI carefully observes that "unless counterbalanced, majoritarian control also creates a potential risk for many investors." Id. 
legislators and judges, minority protection devices require active vigilance. Corporate law springs into action-becomes nontrivial ${ }^{35}$-on behalf of minority shareholders.

Such special attention should not be mistaken for effective minority control. The debacles of Enron, WorldCom, and others demonstrate that despite the protective stance of corporate law, minority investors may yet be imperiled by the manipulations of controlling persons. Moreover, minority shareholder protection generally does not empower the minority to make decisions for the corporation. ${ }^{36}$ The business judgment rule, in particular, operates to insulate most corporate decisions from judicial review, at least in the absence of fraud, illegality, or conflict of interest. ${ }^{37}$

This is not to say that minority shareholder protection operates only occasionally, intervening in extreme cases. Rather, it is omnipresentstructuring mergers, regulating securities offerings, and guiding deliberative processes. Due consideration of minority interests is an ordinary part of corporate life, mandated by law.

Moreover, shareholder democracy does not permit the majority to set company policy directly. Shareholder resolutions are merely suggestions to the board of directors, and attempts to control the directors by majority vote will be rebuffed: "The directors are not servants to obey directions and orders given them by majority shareholders." 38 Directors must serve all shareholders, not just those wielding majority power: "[T]he management and control of the company are entrusted to the directors for the benefit and protection of all the shareholders." ${ }^{39}$ Indeed, this may help explain why we have boards of directors in the first place. The board, which is responsible to all shareholders, not just to those who elected them, insulates management from the direct command of controlling shareholders. ${ }^{40}$

35. See Bernard S. Black, Is Corporate Law Trivial?: A Political and Economic Analysis, 84 Nw. U. L. REV. 542 (1990).

36. See S. Pac. Co. v. Bogert, 250 U.S. 483, 487-88 (1919). But see Julián Javier Garza, Rethinking Corporate Governance: The Role of Minority Shareholders-A Comparative Study, 31 ST. MARY'S L.J. 613, 617 (2000) (highlighting the "power of the minority" within the corporation).

37. 2 F.H. O'NEAL \& R. THOMPSON, O'NEAL'S OPPRESSION OF MINORITY SHAREHOLDERS $\S 10: 04$ (2d ed. 1985 \& Supp. 2003); Franklin A. Gevurtz, The Business Judgment Rule: Meaningless Verbiage or Misguided Notion?, 67 S. CAL. L. REV. 287, 291 (1994).

38. HENRY WINTHROP BALLANTINE, BALLANTINE ON CORPORATIONS 122 (1946).

39. Id.

40. Morten Bennedsen, Why Do Firms Have Boards? (SSRN Elec. Library, Working Paper No. $303,680,2002$ ), http://papers.ssm.com/sol3/papers.cfm?abstract_id $=303680$ (concluding on the basis of an empirical study of Danish firms that boards are used in closely held corporations to protect noncontrolling shareholders from exploitation by controlling shareholders). But see Stephen M. Bainbridge, Why a Board? Group Decisionmaking in Corporate Governance, 55 VAND. L. REV. 1 (2002) (arguing that decisionmaking is entrusted to a board rather than individual officers because of the likely superiority of group decisionmaking over individual decisionmaking); Franklin A. Gevurtz, The Historical and Political Origins of the Corporate Board of Directors (2002) (unpublished manuscript, on file with author) (arguing that boards of directors originally served as symbols of the consent of the governed). 
A potential confusion in corporate law stems from the use of the terms "shareholder" and "stockholder" to refer to minority shareholders. Oftentimes, these terms are used to refer to the shareholders who do not control the corporation-that is, "minority shareholders." When Berle and Means, for example, describe the lack of control of the "stockholder" in the modern corporation they mean stockholders other than controlling stockholders. ${ }^{41}$ They thus emphasize that lack of control is the usual position of the stockholder in the modern corporation. In such a corporation, every shareholder is a minority shareholder. Even though they recognize that this is only a dominant trend, not a characteristic of all corporations, $^{42}$ they still employ "stockholder" or "shareholder" as shorthand for "minority shareholder."

To combat such confusion, three clarifications of my own are in order here. First, by "minority shareholders," I mean noncontrolling shareholders. In many corporations such minority shareholders may together hold a majority of the shares-but only rarely if ever act in concert to exercise their potential voting power. It follows that controlling shareholders can hold a minority of shares yet exercise control, a seeming paradox that corporate law has long understood. ${ }^{43}$ Second, I do not mean to suggest that corporate law's concern is exclusively with minority shareholders. There are certainly other constituencies that corporate law serves, including creditors (through doctrines such as fraudulent transfer and veil piercing) and perhaps also employees and the community. Finally, corporate law's rise to the defense of the powerless is, of course, woefully incomplete; corporate law does not serve workers, consumers, or the community with nearly the same enthusiasm it offers to minority shareholders. Indeed, Henry Ford's ostensible effort to the contrary was rebuffed by the court. But among the shareholding constituency alone, this Part reveals that minority shareholder protection, explicitly and implicitly, animates much of corporate law.

I continue here my rereading of the corporate law canon.

41. See, e.g., Adolf A. Berle, JR. \& Gardiner C. MEANS, THE Modern Corporation AND PRIVATE PROPERTY 66-116 (rev. ed. 1967) [hereinafter BERLE \& MEANS, THE MODERN CORPORATION 1967]; id. at 83 ("[T]he usual stockholder has little power over the affairs of the enterprise and his vote ... is rarely capable of being used as an instrument of democratic control .... The bulk of owners have in fact almost no control over the enterprise."); ADOLF A. BERLE, JR. \& GARDINER C. MEANS, THE MODERN CORPORATION AND PRIVATE PROPERTY 27879 (1932) [hereinafter BERLE \& MEANS, THE MODERN CORPORATION 1932]; id. at 338 ("The stockholder has surrendered control over his wealth.").

42. See BERLE \& MEANS, THE MODERN CORPORATION 1967, supra note 41, at 116 (showing that more than forty percent of the 200 largest corporations had controlling shareholders).

43. See infra notes $262-268$ and accompanying text. 


\section{A. Cases}

Dodge v. Ford is not unique. Contemporary readings of the prominent corporate law cases have often elided their central concern with minority protection. I analyze here three familiar cases, chosen not because of some unusual sympathy for minorities, but because they show that such sympathy animates even the foundational cases.

\section{Perlman v. Feldmann and Control Premia}

Set in the backdrop of the Korean War, the case of Perlman $v$. Feldmann ${ }^{44}$ demonstrates the high standards that courts impose on controlling shareholders to protect the rights of minority shareholders. Taking advantage of the steel shortage resulting from the war, C. Russell Feldmann, the dominant shareholder ${ }^{45}$ of the Newport Steel Company (and also its chairman and president), sold his control block to a group of steel buyers "who were interested in securing a source of supply in a market becoming ever tighter." ${ }^{, 46}$ Minority shareholder Perlman brought a derivative action seeking to force Feldmann to share the part of his sale proceeds attributable to the sale of corporate control, including the power to determine the allocation of the corporation's steel among potential buyers.

The Second Circuit sided with the minority plaintiff. It held that Feldmann had failed to meet that "high standard... which we and other courts have come to expect and demand of corporate fiduciaries" ${ }^{, 47}$ because he had sought to appropriate for himself the market advantage that belonged to the corporation as a whole. ${ }^{48}$

While the case has been criticized as reflecting an "equal opportunity" approach to the division of the premium appurtenant to a sale of control, ${ }^{49}$ it seems better understood exactly on the terms stated in Judge Clark's opinion for the court: " $[I]$ n a time of market shortage, where a call on a corporation's product commands an unusually large premium,... a

44. 219 F.2d 173 (2d Cir. 1955).

45. Though Feldmann did not own a majority of shares, the court recognized that he had "working control" of the corporation. Id. at $174 \mathrm{n} .1$; see also id. at 178 (Swan, J., dissenting). In Sections II.D and III.C, I highlight corporate law's sophisticated understanding of control even in the absence of majority ownership.

46. Id. at 175 .

47. $I d$. at 176 .

48. The court even invoked then-Chief Judge Cardozo's demanding duty of the finest loyalty. See id. (citing Meinhard v. Salmon, 164 N.E. 545 (N.Y. 1928)).

49. See Einer Elhauge, The Triggering Function of Sale of Control Doctrine, 59 U. CHI. L. REV. 1465, 1475 (1992) (observing that "many commentators have concluded that the case's natural implication was that the duty to share the control premium should apply in all cases"). But see William D. Andrews, The Stockholder's Right to Equal Opportunity in the Sale of Shares, 78 HARV. L. REV. 505, 506 (1965) (arguing that the sale of control by a controlling shareholder is a corporate opportunity to which all shareholders are entitled). 
fiduciary may not appropriate to himself the value of this premium." purchasers of the controlling stake in the company bought control in order to guarantee themselves a supply of steel during wartime. For this, the purchasers can themselves be castigated for violating their duty of loyalty to the corporation by not allocating the corporate product in accordance solely with the interests of the corporation. ${ }^{51}$ Feldmann's wrongdoing was in countenancing this exploitation. ${ }^{52}$

My interest in the case is in why the court intervened. Who was harmed by the arrangement? Feldmann, of course, was quite happy with it, as were the new controlling shareholders of the corporation. At the same time, future holders of corporate stock would be indifferent; they would presumably purchase the stock with full knowledge of the identity of the controlling shareholders and the likely effect of those shareholders' actions on corporate profits. Employees would seem largely unaffected by the change, and might even benefit from the additional security of always selling to a single buyer-namely, the acquiring company.

Perhaps it might be offered that the corporation itself was harmed-its value as a whole diminished by its capture by one buyer. But a harm to the abstract entity of the corporation seems an inadequate basis upon which to justify judicial intervention. Rather, it is clear that the harm done was to minority shareholders such as Perlman. As the court noted, its concern was with Feldmann's "coventurers." 53 The court underlined this concern in its remedy: The recovery, it commanded, should go to the minority shareholder plaintiffs instead of the corporation as a whole, because a recovery by the corporation would be shared with the controlling shareholder. ${ }^{54}$

50. 219 F.2d at 178. But see Frank H. Easterbrook \& Daniel R. Fischel, Corporate Control Transactions, 91 YALE L.J. 698, 717-18 (1982) (arguing that the purchasers of the controlling stake did not appropriate any value that properly belonged to the corporation).

51. See Andrews, supra note 49; see also Alfred Hill, The Sale of Controlling Shares, 70 HARV. L. REV. 986, 1019-20 (1957) (applying the "fiduciary principle to find that old managers were themselves guilty of a breach of trust if they knowingly turned control over to [exploitative] buyers").

52. Perlman has often been characterized as a "looting" case. See, e.g., Richard A. Booth, Derivative Suits and Pro Rata Recovery, 61 GEO. WASH. L. REV. 1274, 1281 (1993) ("[I]t seems clear that the court ruled in favor of the plaintiffs because it concluded that under the circumstances the premium probably derived from the opportunity to loot Newport later. If the premium had arisen because of additional value perceived by the buyers, there would have been no damage to the remaining shareholders.").

53. 219 F.2d at 178; see also Booth, supra note 52, at 1281 ("The reason given by the Second Circuit for the remedy was that the premium was at the expense of the outside shareholders.").

54. 219 F.2d at 178. 
Perlman v. Feldmann is a controversial case $;^{55}$ recent cases on control premia have tended to go the other way. ${ }^{56}$ But even contemporary cases on control premia show a marked concern for minority rights. ${ }^{57}$ In a recent ruling in favor of a controlling shareholder group, for example, the Delaware Chancery Court first reviewed and dismissed any "threat of exploitation or even unfairness towards a vulnerable minority that might arguably justify discrimination against a controlling block of stock." ${ }^{\text {"58 }}$ The actions of controlling shareholder are scrutinized carefully to reveal any impermissible unfairness to the minority.

I begin with the case of the sale of a controlling block because it is here that the law might be said to put stress on my thesis. ${ }^{59}$ After all, the law generally permits the controlling shareholder to sell her shares at a "control premium. ${ }^{, 60}$ In so doing, the law recognizes and validates the extra value of control. But it does so on behalf of the minority. The case for the unequal distribution of the control premium turns on the question, which rule makes minority shareholders better off ${ }^{61}$

55. See 1 O'NEAL \& THOMPSON, supra note $37, \S 4: 07$ ("The Perlman ... opinion[], though widely discussed by commentators, ha[s] not been widely followed."). Perlman remains, however, a fixture in corporate law casebooks. See, e.g., JESSE H. CHOPER ET AL., CASES AND MATERIALS ON CORPORATIONS 1019 (5th ed. 2000); MELVIN ARON EISENBERG, CORPORATIONS AND OTHER BUSINESS ORGANIZATIONS 529 (concise 8th ed. 2000); ROBERT W. HAMILTON, CORPORATIONS INCLUDING PARTNERSHIPS AND LIMITED LIABILITY COMPANIES: CASES AND MATERIALS 591 (7th ed. 2001); WILLIAM A. KLEIN ET AL., BUSINESS ASSOCIATIONS-CASES AND MATERIALS ON AGENCY, PARTNERSHIPS, AND CORPORATIONS 683 (4th ed. 2000).

56. See John C. Coffee, Jr., Transfers of Control and the Quest for Efficiency: Can Delaware Law Encourage Efficient Transactions While Chilling Inefficient Ones?, 21 DEL. J. CoRP. L. 359, 381 (1996) (observing that "there remains considerable doubt that Perlman would be followed today"); RONALD J. Gilson \& JEFFrEY N. GORDON, CONTROLling CONTROLling Shareholders 11 (Columbia Law Sch. Ctr. for Law \& Econ. Studies, Working Paper No. 228, Stanford Law Sch. John M. Olin Program in Law \& Econ., Working Paper No. 262, 2003), http://papers.ssrn.com/sol3/papers.cfm?abstract_id $=417181$.

57. See, e.g., Jones v. H.F. Ahmanson \& Co., 460 P.2d 464, 471-74 (Cal. 1969) (holding that majority shareholders, who exchanged controlling shares for personal gain, owed a fiduciary duty to minority shareholders to act fairly, justly, and equitably).

58. Mendel v. Carroll, 651 A.2d 297, 304 (Del. Ch. 1994).

59. An interesting counterpoint is the use of "tag-along" rights granted to minority investors in the Novo Mercado in Brazil. These rights guarantee minority investors an equal opportunity to sell upon a change of control and a proportionate share of the control premium. See Coffee, supra note 20, at 1807; Craig Karmin \& Jonathan Karp, Brazilian Market Tries Friendly Approach: Novo Mercado's Rules Aim To Help Minority Holders, WALl ST. J., May 10, 2001, at C1.

60. See, e.g., Grobow v. Perot, 539 A.2d 180, 189 (Del. 1988) (permitting a controlling shareholder to dispose, under certain circumstances, of her shares at a premium without requiring the same price to be made available to minority shareholders), overruled on other grounds by Brehm v. Eisner, 746 A.2d 244 (Del. 2000); I PRINCIPLES OF CORPORATE GOVERNANCE, supra note $34, \S 5.16$. At the same time, however, various legal provisions disfavor a control premium. See Coffee, supra note 56, at 371-401.

61. See CHOPER ET AL., supra note 55, at 1019; ROBERT ClaRK, CORPORATE LAW § 11.4.5 (1986); William D. Andrews, The Stockholder's Right to Equal Opportunity in the Sale of Shares, 78 HARV. L. REV. 505, 517-19, 522-28 (1965); Berle, supra note 33, at 1214; Hill, supra note 51, at 1010-28; see also Gilson \& Gordon, supra note 56, at 12 (evaluating the ideal regulation of control premia from the perspective of minority shareholders). 
Corporate law here enshrines a Rawlsian egalitarianism: ${ }^{62}$ Inequality is permissible, but only because it benefits the least well off. The premium exacted upon transfer of control redounds ultimately to the benefit of the minority shareholders, absent exploitation of the private benefits of control that fiduciary duties seek to check. The shareholder wealth maximization norm, we see, does not completely capture the concerns of corporate law.

\section{Joy v. North and Power Within the Corporation}

Luminously written, the case of Joy v. North offers a sophisticated understanding of relations within the corporate power structure. ${ }^{63}$ Whereas Perlman v. Feldmann involves judicial scrutiny of a controlling shareholder for compliance with fiduciary duties, Joy $v$. North involves judicial scrutiny of a corporate board, again for compliance with fiduciary duties. In careful language, Judge Winter's opinion for the Second Circuit in Joy v. North justifies its intrusion into corporate affairs.

Minority shareholder Doris Joy sued the directors and officers of Citytrust, Inc. for, inter alia, breach of fiduciary duty. Joy complained that Citytrust had extended financing to real estate development company Katz Corporation without regard for the merits of the loans. Citytrust had done so while the son of its CEO, Nelson North, was employed by Katz. ${ }^{64}$ After Joy initiated suit, Citytrust's board of directors established a "Special Litigation Committee" of two new board members. After study, the Committee recommended discontinuing the suit with respect to the bulk of the defendant directors. ${ }^{65}$ Disinclined to defer to the Committee's judgment, the Second Circuit (which was acting in prediction of Connecticut law) reviewed the likelihood of success in the litigation as well as the size of any likely award. Weighing these factors against the costs of the litigation, the court concluded that litigation was clearly warranted.

Joy v. North can be understood simply as the natural working out of the principle of shareholder wealth maximization. The court intervened to permit a shareholder to sue where the board of directors had plainly derogated from its responsibility to maximize corporate returns. While not disagreeing with this reading of Joy, I suggest that Joy can only be understood as a case dissecting power relations, even if such dissection is in the service of shareholder wealth. The court's decision to intervene, over

62. Rawls accepts inequalities where the improvement in fortunes of those at the top simultaneously benefits those at the bottom. JOHN RAWLS, A THEORY OF JUSTICE 68 (rev. ed. 1999) ("What . . . can possibly justify this kind of initial inequality in life prospects? According to the difference principle, it is justifiable only if the difference in expectation is to the advantage of the representative man who is worse off, in this case the representative unskilled worker.").

63. 692 F.2d 880 (2d Cir. 1982).

64. Id. at 894 .

65. Id. at $883-84$. 
the dissent's objection of "overregulation," 66 resulted from the court's concern with power relations in the corporate sphere.

The court was concerned about the absence of power in the shareholder class. Apparently without a controlling shareholder, ${ }^{67}$ Citytrust lay at the mercy of its management. Citytrust thus represented the classic BerleMeans corporation, with a dispersed multitude of public investors and a professional management. ${ }^{68}$ In such a corporation, shareholders, each with a small stake in the enterprise, would lack the financial incentive to watch over the enterprise or to intervene in cases of managerial failure or abuse. Control, according to Berle and Means, would therefore rest in the professional management. ${ }^{69}$ In the absence of a controlling shareholder, every shareholder becomes a minority shareholder, requiring judicial solicitude.

The separation of ownership and control in the modern public corporation implied a need for the state to protect minority shareholders from the "rapaciousness of corporate managers." ${ }^{70}$ In contemporary terms, shareholder powerlessness might be explained in terms of "rational apathy."71 Shareholder powerlessness is itself rational. The empowered shareholder, who takes upon herself the entire cost of direct action with only the promise of a proportional share of any award, acts contrary to her own interest and allows others to free-ride on her efforts. Because of rational limits on shareholder monitoring, the likelihood of abuse by controlling directors and officers grows.

This seems to be borne out in the case of Citytrust. The challenged transactions-the loans to Katz, each new one compounding the error of the previous ones-occurred over years under the supervision of Citytrust's management. There is a strong suggestion that management exploited its control for private benefits, with the son of the chief executive profiting from the loans extended by Citytrust. ${ }^{72}$

66. Id. at 898 (Cardamone, J., concurring in part and dissenting in part).

67. The lack of a controlling shareholder is implicit in the court's reference to the rationale for the derivative suit lying in a dispersed ownership structure, $i d$. at $886-87$, and in the absence of any reference to any controlling shareholder or shareholder group.

68. See BERLE \& MEANS, THE MODERN CORPORATION 1932, supra note 41, at 278-79; see also Alfred D. Chandler, JR., The Visible Hand: The Managerial Revolution in AMERICAN BUSINESS (1977) (arguing that control of many American corporations has passed into the hands of a professional class).

69. BERLE \& MEANS, THE MODERN CORPORATION 1932, supra note 41, at 278-79.

70. 9 ZOLMAN CAVITCH, BUSINESS ORGaNIZATIONS WITH TAX PLANNING $\S 108.01$ n.3 (2003) (concluding that, because of the separation of ownership and control in many public corporations, "[c]orporate law... must shield shareholders from the rapaciousness of corporate managers").

71. CHOPER ET AL., supra note 55, at 544-46.

72. Joy, 692 F.2d at 894 . 
The backbone of shareholder power, derivative suits can be understood as grounded in minority shareholder protection. ${ }^{73}$ Given the separation of ownership and control, minority shareholders needed a way to call directors to account. Justice Jackson described derivative suits as a "remedy born of stockholder helplessness," stockholders were "numerous and scattered" and held but "small interests." "75 Derivative suits would be unnecessary to protect the interests of controlling shareholders, who, almost by definition, are likely to hold a large enough stake in the corporation to justify the cost of monitoring against managerial wrongdoing. ${ }^{76}$ Not only do controlling shareholders have the incentive to act, but they also have the power: As the Illinois Supreme Court has observed, "[A] majority or controlling shareholder can usually persuade the corporation to sue in its own name."77

The Berle-Means hypothesis explains why corporate law favors minorities - and why the Second Circuit intervened in Joy v. North. Left to themselves, minorities are presumed to be without adequate power or incentive to prevent abuse. ${ }^{78}$ To echo the words of the Second Circuit, "[T] he stake of each shareholder ... is usually too small ... and the costs of organizing . . . are usually prohibitively high."

73. BALLANTINE, supra note 38 , at 334 ("Such suits are the principal remedy by which defrauded minority shareholders may call directors, officers, promoters and controlling shareholders to account . . . ."); Bert S. Prunty, Jr., The Shareholders' Derivative Suit: Notes on Its Derivation, 32 N.Y.U. L. REv. 980, 994 (1957) (observing that, at its origins, the derivative action "may be viewed as another application of the political principle of protection for minorities"). That derivative suits protect minority shareholders is further demonstrated by the fact that most jurisdictions do not condition a derivative suit on the minority shareholder plaintiff's making a demand on all shareholders. See DEBORAH A. DEMOtT, SHAREHOLDER DERIVATIVE ACTIONS: LAW AND PRACTICE $\S$ 5:02 (2002) (concluding that "[f]ew recent cases ultimately require demand on shareholders"). Even states that require demand on shareholders excuse it where it would be futile because "a majority of the stock was owned or controlled by alleged wrongdoers antagonistic to the suit." Id. \& 5:04.

74. Cohen v. Beneficial Indus. Loan Corp., 337 U.S. 541, 548 (1949).

75. Id. at 547 .

76. This is well accepted even by prominent contractarians. See, e.g., Henry N. Butler \& Larry E. Ribstein, Opting Out of Fiduciary Duties: A Response to the Anti-Contractarians, 65 WASH. L. REV. 1, 24 n.97 (1990).

77. Brown v. Tenney, 532 N.E.2d 230, 232-33 (Ill. 1988); see also Mary Elizabeth Matthews, Derivative Suits and the Similarly Situated Shareholder Requirement, 8 DEPAUL BUS. L.J. 1, 12 (1995) (observing that "[t]he majority through their control of the board could cause the suit to be brought directly").

78. But, as in any instantiation of power, the power granted to minorities to bring suit on behalf of the corporation can be abused. After an empirical study of shareholder suits against public corporations, Roberta Romano concludes that "the principal beneficiaries . . a appear to be attorneys." Roberta Romano, The Shareholder Suit: Litigation Without Foundation?, 7 J.L. ECON. \& ORG. 55, 84 (1991). State legislatures have accordingly placed stringent requirements on derivative actions to assure that suits are well-founded. See, e.g., CAL. CORP. CODE $\S 800$ (West 2003); N.Y. BUS. CORP. LAW $\S 627$ (McKinney 2003); see also Cohen, 337 U.S. 541 (upholding, against due process and equal protection challenges, a New Jersey statute requiring shareholders with very small holdings to post bond before bringing a derivative claim).

79. Joy v. North, 692 F.2d 880, 886-87 (2d Cir. 1982). 
The court considered not only power relations between shareholders and managers, but also relations within the management itself. Though the possible conflict of interest in the Katz transactions was limited to CEO North, that did not acquit the remaining directors of the conflict. Nelson North, the court tells us, "completely dominated" the management of the company. ${ }^{80}$ Though North had recused himself from voting on the Katz transactions, the court dismissed this as a kind of false propriety: "[North's] fastidiousness appears to have been limited to the formality of voting, for the Report [of the Special Litigation Committee] strongly suggests that North was deeply involved in the Katz transactions . . .."8

The court also refused to defer to the judgment of the independent directors appointed to the Special Litigation Committee. ${ }^{82}$ The court doubted their objectivity, noting that they were appointed by the defendants themselves. ${ }^{83}$ The court explained, "It is not cynical to expect that such committees will tend to view derivative actions against the other directors with skepticism., ${ }^{, 84}$ The court worried that deferring to the Committee's assessment would preclude shareholders from enforcing their rights. ${ }^{85}$

As we have seen, the Second Circuit's assessment in Joy v. North of the workings of the corporate power structure led to its conclusion that intervention is necessary to protect shareholders who would otherwise be vulnerable. ${ }^{86}$ Such examination of the underlying power relations is wellprecedented in corporate law. For example, in Globe Woolen Co. v. Utica Gas \& Electric, Co., ${ }^{87}$ then-Judge Cardozo famously "probe[d] beneath the surface" ${ }^{, 88}$ of corporate relations, recognizing that "[a] dominating influence may be exerted in other ways than by a vote. ${ }^{, 89}$

80. Id. at 894 . The court went on to describe some of the mechanisms by which North dominated the board, including not distributing agendas or materials before board meetings. Id.

81. Id.

82. Id. Decisions of special litigation committees appointed in corporations with controlling shareholders also require great scrutiny. See Alford v. Shaw, 358 S.E.2d 323, 326 (N.C. 1987).

83. Joy, 692 F.2d at 888.

84. Id.; cf. Dynamics Corp. of Am. v. CTS Corp., 794 F.2d 250, 256 (7th Cir. 1986) (Posner, J.) ("The so-called outsiders ... are often friends of the insiders."), rev'd on other grounds, 481 U.S. 69 (1987).

85. Joy, 692 F.2d at 889 ("The traditional fiduciary obligations of directors and officers under Connecticut law can hardly be said to exist if the sole enforcement method can be eliminated on a recommendation of the defendants' appointees."). Deference to a special litigation committee would work especially to the disadvantage of minority shareholders in the context of a corporation with a controlling shareholder, as the case of Alford v. Shaw makes plain. 358 S.E.2d at 326.

86. Joy, 692 F.2d at 889 (stating that a contrary "view essentially vests power in defendant's appointees to bring about their dismissal").

87. 121 N.E. 378 (N.Y. 1918).

88. Id. at 379 .

89. Id. at $379-80$. 


\section{Revlon v. MacAndrews \& Forbes Holdings and Fairness in Control Transactions}

The "battle for corporate control""90 over Revlon turned on the legality of the efforts of the Revlon board to thwart a hostile takeover by favoring a "white knight."91 The hostile bidder challenged the board's favoritism toward its preferred acquirer as contrary to the board's obligations to the company's shareholders. The Delaware Supreme Court sided with the hostile bidder. When the sale of the company became "inevitable," court declared, "[ $t]$ he directors' role changed from defenders of the corporate bastion to auctioneers charged with getting the best price for the stockholders at a sale of the company." certain, the battle for corporate control must be won on the basis of the best value for shareholders. ${ }^{94}$

The court's concern for shareholders is apparent. ${ }^{95}$ By preferring the inferior offer of the white knight, Revlon's board failed to maximize the price the shareholders would receive for their stock. This failure, the court held, violated the board's fiduciary duties of loyalty and care owed to the shareholders. ${ }^{96}$

While Revlon's support for shareholders as a class is evident, its role in protecting minority shareholders specifically becomes manifest only in subsequent cases. Indeed, minority shareholders offer a key to understanding Delaware's complex case law on takeover defenses. Under that case law, courts at times intervene to block a board's defenses, and at other times sit idly on the sidelines. Commentators have long sought to find coherence in this jurisprudence, suggesting, for example, that it can be explained on the ground that directors should make all business decisions

90. Revlon, Inc. v. MacAndrews \& Forbes Holdings, Inc., 506 A.2d 173, 175 (Del. 1986).

91. Id. at 184 .

92. Id.

93. Id. at 182 .

94. Later cases have clarified that auctions are not the only means by which a board can assure that it is obtaining the best value for shareholders. See Citron v. Fairchild Camera \& Instrument Corp., 569 A.2d 53, 68 (Del. 1989); Barkan v. Amsted Indus. Inc., 567 A.2d 1279, 1286-87 (Del. 1989); Mills Acquisition Co. v. Macmillan, Inc., 559 A.2d 1261, 1286 (Del. 1989) ("Directors are not required by Delaware law to conduct an auction according to some standard formula ....").

95. See, e.g., Bernard Black \& Reinier Kraakman, Delaware's Takeover Law: The Uncertain Search for Hidden Value, 96 Nw. U. L. REV. 521, 527 (2002) (describing Revlon's affirmation of "shareholder primacy"). My point here is to observe the court's concern for shareholders, not to argue for the wisdom of its judgment. John Coffee has argued that a hostile takeover may ultimately prove detrimental to shareholders because it may be motivated by considerations other than efficiencies. John C. Coffee, Jr., Regulating the Market for Corporate Control: A Critical Assessment of the Tender Offer's Role in Corporate Governance, 84 COLUM. L. REV. 1145, 1153 (1984).

96. Revlon, 506 A.2d at 184. 
subject only to shareholder removal ${ }^{97}$ or that directors best understand the true value of a corporation. ${ }^{98}$ I propose here that whether courts intervene turns in large part on how minority shareholders will fare under the board's plan. $^{99}$

Judicial concern for minority shareholders during a change of control was clarified in the case of Paramount Communications Inc. v. QVC Network. ${ }^{100}$ Paramount, which had earlier been the unwelcome bidder for Time, ${ }^{101}$ now found itself the subject of unfriendly advances from QVC. Before QVC made its overtures, Paramount's board had been planning a merger with Viacom. QVC's interest led the Paramount board to take some defensive steps that would make the planned Viacom merger difficult to dislodge. QVC sued, arguing that the Paramount board violated its fiduciary obligations. While the Delaware Supreme Court had approved the Time board's proposed merger with Warner Communications in the face of Paramount's hostile bid, ${ }^{102}$ the court now recoiled from affirming the Paramount board's proposed merger with Viacom in the face of QVC's hostile bid.

The difference between the decisions in Time and $Q V C$ has been explained by the effect of the merger on control in the corporation. But closer examination reveals that control is at issue only to the extent that it implies risk to minority shareholders. The court distinguished the proposed Time-Warner merger (which it approved) and the proposed ParamountViacom merger (which it did not approve) as follows: "Time would be owned by a fluid aggregation of unaffiliated stockholders both before and after the merger," 103 whereas the Paramount-Viacom merger would "shift control of Paramount from the public stockholders to a controlling stockholder, Viacom." "104 That is, in the case of Time-Warner, control would remain where it lay-in the anonymous stock market-while in Paramount-Viacom, control would shift from the market to Viacom, and

97. See Marcel Kahan, Paramount or Paradox: The Delaware Supreme Court's Takeover Jurisprudence, 19 J. CORP. L. 583 (1994).

98. See Black \& Kraakman, supra note 95 , at 521.

99. A student note reaches a similar conclusion, as does an article by two scholars. See Kimble C. Cannon \& Patrick J. Tangney, Protection of Minority Shareholder Rights Under Delaware Law: Reinforcing Shareholders as Residual Claimants and Maximizing Long-Term Share Value by Restricting Directorial Discretion, 1995 COLUM. BUS. L. REV. 725, 773 ("QVC is really a case about the protection of minority shareholders in that Vice Chancellor Jacobs recognized that the shareholders of Paramount form a constructive minority and invoked Revlon to protect that constructive minority."); Alexander B. Johnson, Note, Is Revlon Only Cosmetic?: Structuring a Merger in the Mid-1990s, 63 FORDHAM L. REV. 2271, 2313 (1995) ("Revlon duties arise largely to protect minority shareholders when control is transferred from them.").

100. 637 A.2d 34 (Del. 1993).

101. See Paramount Communications, Inc. v. Time, Inc., 571 A.2d 1140 (Del. 1989).

102. Id. at 1154-55.

103. $Q V C, 637$ A.2d at 46 .

104. Id. at 48 . 
within Viacom to a particular person, Sumner Redstone, Viacom's controlling shareholder. Indeed, Redstone would become the "controlling stockholder of the combined company."105

But what is it about a change in control that spurs the court to action? The concern is that shareholders, who earlier were more or less equal, would now become minority shareholders in an enterprise controlled by someone else. And, as minority shareholders, they might face exploitation, as the court explained:

In the absence of devices protecting the minority stockholders, stockholder votes are likely to become mere formalities where there is a majority stockholder. For example, minority stockholders can be deprived of a continuing equity interest in their corporation by means of a cash-out merger. Absent effective protective provisions, minority stockholders must rely for protection solely on the fiduciary duties owed to them by the directors and the majority stockholder, since the minority stockholders have lost the power to influence corporate direction through the ballot. ${ }^{106}$

The key distinction between Time and QVC seems to be that in Time, "'effectuation of the merger would not have subjected Time shareholders to the risks and consequences of holders of minority shares." 107 That is, the Paramount merger would have put that company's shareholders at the mercy of a controlling shareholder. The court acted because of its concern for the minority shareholder in the presence of a controlling shareholder.

In so doing, the Delaware Supreme Court continued the long tradition of vigilance in the face of controlling shareholders. The common law has long imposed special fiduciary obligations on controlling shareholders-obligations that minority shareholders do not share. The Supreme Court's well-cited dictum in Pepper $v$. Litton stands as a prominent example: "A director is a fiduciary. So is a dominant or controlling stockholder or group of stockholders." 108 Indeed, many of the standard corporate law cases turn on the special responsibilities of controlling shareholders. In Sinclair Oil Corp. v. Levien, for example, the Delaware Supreme Court held that the parent corporation of a majority-

105. Id. at 38 .

106. Id. at 42-43 (citing Weinberger v. UOP, Inc., 457 A.2d 701, 703 (Del. 1983) (footnote omitted)).

107. Id. at 47 (quoting Paramount Communications Inc. v. Time, Inc., Nos. 10866, 10670 \& 10935, 1989 WL 79880, at *23 (Del. Ch. July 1[4], 1989) (Allen, C.)).

108. 308 U.S. 295, 306 (1939) (citation omitted); see also S. Pac. Co. v. Bogert, 250 U.S. $483,487-88$ (1919) ("The rule of corporation law and of equity invoked is well settled and has been often applied. The majority has the right to control; but when it does so, it occupies a fiduciary relation toward the minority, as much so as the corporation itself or its officers and directors."). 
owned subsidiary had violated its fiduciary obligation as a controlling shareholder by using its power to cause the subsidiary to fail to enforce a contractual right against another subsidiary of the parent corporation. ${ }^{109}$ Zahn v. Transamerica Corp. shows how the obligations of controlling shareholders devolve on the board of directors, which must act disinterestedly with respect to the various classes of shareholders. ${ }^{110}$ Weinberger v. UOP, Inc., one of the most widely cited of corporate cases, imposed an "unflinching" mandate upon directors in transactions involving a controlling shareholder to "demonstrate their utmost good faith and the most scrupulous inherent fairness of the bargain." "Cases from California and Massachusetts go further still, demanding duties from controlling shareholders that mirror those typical of a partnership. ${ }^{112}$

But in $Q V C$, the Delaware court seemed to suggest that even such special legal protections for minority shareholders might not be enough. The fiduciary obligations imposed on controlling shareholders did not eradicate the "risks and consequences of holders of minority shares." 113 If the shareholders were to suffer such a disadvantage, the court explained, they must be compensated-in the form of a premium paid by the entity taking control. According to the court, "[T] entitled to receive, and should receive, a control premium ...."114 The loss of power implicated by the introduction of a controlling shareholder required compensation.

The court suggested yet another alternative, an alternative that confirms the court's ultimate concern for the risks associated with minority shareholding. In structuring the merger, the board could, the court observes, have put into place "devices protecting the minority stockholders." 115 In lieu of a control premium, the proposed merger could have granted minority shareholders "protective devices of significant value." 116 Such devices could have included "supermajority voting provisions, majority of the minority requirements, etc." 117 That is, the merger might have protected minority shareholders through procedural devices that ensured the

109. 280 A.2d 717, 723 (Del. 1971).

110. 162 F.2d 36 (3d Cir. 1947).

111. 457 A.2d 701, 710 (Del. 1983).

112. E.g., Jones v. H.F. Ahmanson \& Co., 460 P.2d 464 (Cal. 1969) (finding a cause of action for minority shareholders where majority shareholders had formed a new corporation whose principal asset was their control block of shares in the old corporation, thereby creating a public market for majority shares, but not minority shares); Donahue v. Rodd Electrotype Co., 328 N.E.2d 505 (Mass. 1975) (holding that shareholders in a close corporation owe each other an enhanced fiduciary duty of utmost good faith and loyalty, and requiring that minority shareholders have an equal opportunity to have their shares redeemed by the corporation).

113. Paramount Communications Inc. v. QVC Network, 637 A.2d 34, 47 (Del. 1993).

114. Id. at 43 .

115. Id. at 42 .

116. Id at 43.

117. Id. at 42 n. 12. 
possibility of minority power. The court cited its decision in Ivanhoe Partners v. Newmont Mining Corp., ${ }^{118}$ where the board protected minority shareholders against the controlling shareholder through a standstill agreement that limited the controlling shareholder's ownership and voting power. ${ }^{119}$ The option of a procedural safeguard suggests that the Delaware takeover jurisprudence may be more than the "search for hidden value" that Bernard Black and Reinier Kraakman suggest. ${ }^{120}$ To be sure, a belief in "hidden value" - that is, company value not reflected in the stock marketunderlies the Delaware case law. If the Delaware Supreme Court did not believe in hidden value, the case law could be simplified dramatically: The corporate board would simply be obliged to maximize the current market value of the consideration received for the company's stock. ${ }^{121}$ But the court's willingness to countenance transactions that guaranteed minorities some degree of power against the controlling shareholder demonstrates that minority protection serves as a driving concern in the case law.

This is not to say that the court's vigilance is entirely complete. When Chancellor Allen observed that "[c]ontrol of [Paramount and Time] remained in a large, fluid, changeable and changing market," 122 he seemed to deny the basic insight of Berle and Means: that the modern public corporation routinely separates ownership from control. Where Chancellor Allen and the Delaware courts saw control vested in the market writ large, Berle and Means would find control held by corporate management. Although the Delaware courts have recognized the possibility of the abuse of control by management in the face of a hostile acquirer, ${ }^{123}$ the board retains substantial power to rebuff a disfavored bidder ${ }^{124}$-at least when the board's plan does not introduce a new controlling shareholder. Thus, in a corporation without a controlling shareholder, where every shareholder is effectively a minority shareholder, the minority shareholders may remain

118. Id. (citing Ivanhoe Partners v. Newmont Mining Corp., 535 A.2d 1334, 1343 (Del. 1987)).

119. Ivanhoe, 535 A.2d at 1338.

120. Black \& Kraakman, supra note 95 , at 521 .

121. On the question of market prices, see Daniel R. Fischel, Market Evidence in Corporate Law, 69 U. CHI. L. REV. 941 (2002).

122. Paramount Communications Inc. v. Time, Inc., Nos. 10866, $10670 \& 10935,1989$ WL 79880 , at *23 (Del. Ch. July 14, 1989).

123. See, e.g., Unocal Corp. v. Mesa Petroleum Co., 493 A.2d 946, 954 (Del. 1985) (noting the "omnipresent specter that a board may be acting primarily in its own interests" in the face of a hostile takeover bid).

124. See Jennifer Arlen, Designing Mechanisms To Govern Takeover Defenses: Private Contracting, Legal Intervention, and Unforeseen Contingencies, 69 U. CHI. L. REV. 917, 918 (2002) (noting that the Delaware Supreme Court's subsequent decisions have "removed the teeth" from Unocal, allowing a board to "just say no" to acquisition). But see William T. Allen et al., The Great Takeover Debate: A Meditation on Bridging the Conceptual Divide, 69 U. CHI. L. REV. 1067, $1082 \mathrm{n} .51$ (2002) (giving the perspectives of current and former Delaware Chancery Court judges, to wit, that "we do not embrace the views of those who believe that judicial review under, for example, the Unocal standard is toothless"). 
insufficiently protected against the new center of control-management. The familiar collective action problem faced by dispersed shareholders leaves shareholders vulnerable to managerial manipulation. ${ }^{125}$

In all of these decisions, we see the court's ultimate concern for shareholders. This is well understood. But not all shareholders benefit equally from the court's intervention. Courts are especially vigilant with regard to minority shareholders, both in the face of a controlling shareholder and, in the absence of a controlling shareholder, entrenched management. The board of directors bears, in the words of a recent Delaware Supreme Court decision, an "'affirmative duty to protect the interests of the minority." $" 126$ Corporate law here relies implicitly on a theory of power, which I characterize in Part II. Furthermore, the imposition of fiduciary duties on directors and controlling shareholders reflects the law's current stance that market forces do not sufficiently constrain exploitation by those with control.

The myriad of shareholder protections evident in the above cases are remarkable for another reason: They are all judge-made. As Alfred Conard describes it, "The law of corporations would be a sad rag if it were limited to the emanations of the legislatures." 127 The fiduciary duties at the heart of corporate law were devised not by legislators, but by judges. ${ }^{128}$ The derivative suit was a procedural innovation designed by courts to remedy "stockholder helplessness," in the words of the Supreme Court. ${ }^{129}$ The countermajoritarian difficulty posed by unelected judges ${ }^{130}$ does not constrain their activism, at least when they are acting on behalf of minority

125. See Lucian Arye Bebchuk, The Case Against Board Veto in Corporate Takeovers, 69 U. CHI. L. REV. 973 (2002).

126. McMullin v. Beran, 765 A.2d 910, 919 (Del. 2000) (quoting Sealy Mattress Co. of N.J. v. Sealy, Inc., 532 A.2d 1324, 1338 (Del. Ch. 1987)); see also id. at 920 (recognizing a board's "affirmative responsibility to protect ... minority shareholders' interests").

127. Alfred F. CONARD, Corporations IN Perspective 30 (1976). But see LAWRENCE M. FRIEDMAN, A HISTORY OF AMERICAN LAW 511 (2d ed. 1985) ("Private practices and legislation were the major makers of the law of corporations. The courts played a minor role.").

128. See CONARD, supra note 127 , at $34-35$ (remarking on "the fiduciary duty of directors, of which not a word is said in the influential Delaware corporation code").

129. Cohen v. Beneficial Indus. Loan Corp., 337 U.S. 541, 548 (1949); see also Prunty, supra note 73, at 992 (concluding that "the origin of the derivative suit... lies in judicial recognition of a new wrong... for which pre-existing legal procedures proved more or less inadequate"); id. at 986-87 (noting that Robinson v. Smith, 3 Paige Ch. 222 (N.Y. Ch. 1832), is often credited with "paternity of the shareholders' derivative action," but identifying an even earlier origin in dictum in Attorney General v. Utica Insurance Co., 2 Johns. Ch. 371, 389-90 (N.Y. Ch. 1817)).

130. See AleXander M. Bickel, The Least Dangerous Branch: THE Supreme CourT AT THE BAR OF POLITICS (1962) (agreeing that "Justices who are engaged in 'amending' the Constitution are simply a body of electorally irresponsible politicians"). 
shareholders. Judges show little anxiety that they, rather than legislators, lead the fashioning of corporate law. Indeed, legislatures sometimes perceive courts as going too far in fashioning minority protections: After the Delaware Supreme Court's decision in Smith v. Van Gorkom ${ }^{131}$ imposed liability on directors for violating their duty of care by making an uninformed judgment, the Delaware legislature mobilized to eliminate director liability for damages for violations of the duty of care. ${ }^{132}$

The fact that shareholder protections lie in large part in judge-made doctrines may help explain a fundamental finding of prominent empirical work in comparative corporate governance by Rafael La Porta, Florencio Lopez-de-Silanes, Andrei Schleifer, and Robert Vishny. ${ }^{133}$ These authors show that countries with a common law heritage have deeper and more liquid equity markets than do those with a civil law tradition. ${ }^{134}$ The common law origin of much of American shareholder-protection law suggests that judges may be better positioned than legislators to fashion devices to safeguard minority investors. This may be a question of both knowledge and desire. It seems less likely to be a question of authoritythe doctrinal innovations of common law judges could have originated in legislatures. ${ }^{135}$ Perhaps legislators are guided by political interests (in which controlling shareholders and management might be overrepresented), whereas the (usually) appointed judiciary is more likely to put into practice each judge's personal ethical code. Moreover, because judges are themselves likely to belong to the class of minority investors (a class which was, until recently, small relative to the entire population), they may be especially vigilant about transgressions against minority shareholders.

\section{B. Statutes and Constitutions}

Minority shareholders need not rely on common law alone. While the bulk of minority protections arise from judge-made duties, legislatures and constitutional conventions have created or codified minority shareholder

131. 488 A.2d 858 (Del. 1985).

132. See DEL. CODE ANN. tit. 8, $\S 102(b)(7)$ (2002) (permitting corporations to amend their charters to eliminate monetary liability for directors for many violations of the duty of care); see also Malpiede v. Townson, 780 A.2d 1075, 1079 (Del. 2001) (upholding an exculpatory provision authorized by section $102(b)(7))$.

133. La Porta et al., supra note 18; La Porta et al., supra note 19.

134. La Porta et al., supra note 18, at 8-9.

135. Coffee hypothesizes that the common law's advantage over civil law in holding controlling shareholders to their fiduciary duties lies in the common law judge's greater freedom to craft legal rules. John C. Coffee, Jr., Privatization and Corporate Governance: The Lessons from Securities Market Failure, 25 J. CORP. L. 1, 27-28 (1999). This is, of course, only a partial explanation of the result obtained by La Porta et al., because it does not show why civil law legislatures would not step in to create minority protection rules. I suggest here one possible reason why judges might be more likely than legislatures to offer minority shareholder protection. 
protections. ${ }^{136}$ Oppression and unfair prejudice are causes of action available not in civil rights law, but in corporate law. Minority shareholder protections are even enshrined in state constitutions in provisions permitting cumulative voting. This Section examines the statutory and constitutional framework for minority shareholder protection, moving from provisions that are self-evidently directed at minority shareholders (such as oppression, cumulative voting, and appraisal rights), to those that are less evidently so (such as securities regulation). ${ }^{137}$

\section{Oppression}

The cause of action for oppression developed out of the growing recognition that minority shareholders in close corporations were susceptible to abuse by the majority, through non-pro rata distributions and other forms of self-dealing. ${ }^{138}$ The close corporation context, in which personal emoluments such as employment form a significant part of the return on investment and in which ownership shares are relatively illiquid, leaves the minority at heightened risk of exploitation. ${ }^{139} \mathrm{~A}$ concern for minority oppression was evident even in nineteenth-century cases, as observed in the first article ever published in this Journal. ${ }^{140}$ But an

136. Even here, however, judges do much of the work, implementing broad statutory mandates through more particularized rules.

137. I do not consider all corporate minority protections, including many of the devices employed by La Porta and his coauthors to construct their index of minority protection. See La Porta et al., supra note 19, at 1126-31. I also exclude from consideration recent proposed changes to limited liability, a fundamental corporate law doctrine. While it currently serves both controlling and minority equity interests in the corporation, recent scholarship suggests that limited liability should be denied to controlling shareholders. See Nina A. Mendelson, $A$ ControlBased Approach to Shareholder Liability for Corporate Torts, 102 COLUM. L. REV. 1203 (2002). Such a move would reconstruct limited liability as a purely minority protection device. Empirical research suggests that this may already be the default rule. Hansmann's and Kraakman's proposal to deny limited liability for torts would do away with this judicial solicitude for passive minority shareholders. Henry Hansmann \& Reinier Kraakman, Toward Unlimited Shareholder Liability for Corporate Torts, 100 YALE L.J. 1879 (1991); cf. Robert B. Thompson, Unpacking Limited Liability: Direct and Vicarious Liability of Corporate Participants for Torts of the Enterprise, 47 VAND. L. REV. 1, 9 (1994) ("Courts generally refuse to impose liability on shareholders unless they have control of the corporation....").

138. One court offers the following story to dramatize the plight of the minority shareholder in the close corporation: "'There are 51 shares,' said he, 'that are worth $\$ 250,000$. There are 49 shares that are not worth a _." Humphrys v. Winous Co., 133 N.E.2d 780, 783 (Ohio 1956).

139. See J.A.C. Hetherington \& Michael P. Dooley, Illiquidity and Exploitation: A Proposed Statutory Solution to the Remaining Close Corporation Problem, 63 VA. L. REV. 1 (1977); cf. Kiriakides v. Atlas Food Sys. \& Servs., Inc., 541 S.E.2d 257, 267 (S.C. 2001) (finding an "unequal balance of power" between majority and minority shareholders and upholding an oppression claim where the controlling shareholder sought to deprive the minority shareholder of his employment with the corporation and then sought to purchase the minority interest at a discount).

140. See Simeon E. Baldwin, Voting-Trusts, 1 YALE L.J. 1, 14 (1891) (noting the development of corporate law doctrines to "protect each stockholder against oppression by the rest"). 
inconsistent judicial response ${ }^{141}$ led to legislative intervention. "Oppression as a ground for dissolution was included in the Illinois and Pennsylvania corporations acts in 1933, in the first Model Business Corporation Act in 1946, and in the English Companies Act of 1948."142 An action for oppression or unfair prejudice now exists in most states, ${ }^{143}$ and similar doctrines have been developed in equity in other states. ${ }^{144}$ The doctrine also exists in foreign common law jurisdictions. ${ }^{145}$ Pennsylvania law even authorizes a court to appoint a custodian to govern the affairs of a close corporation where "those in control" have oppressed minority shareholders. ${ }^{146}$

The doctrine's status as a device for minority protection is well documented. Perhaps more interesting is the doctrine's persistence in the face of the contractarian reinvention of corporate law. ${ }^{147}$ The law does not require the minority shareholder to protect herself by contract. ${ }^{148}$ Oppression doctrine gives the minority shareholder the benefit of a hypothetical bargain that she never memorialized in an enforceable agreement. ${ }^{149}$ Take the case of Meiselman $v$. Meiselman, ${ }^{150}$ where the North

141. See 2 O'NEAL \& THOMPSON, supra note 37, § 10:04.

142. Robert B. Thompson, The Shareholder's Cause of Action for Oppression, 48 BUS. LAW. 699,709 (1993).

143. Id. at 709 n.70 ("Thirty-seven states base relief on oppression or on language that would be at least as likely to provide relief to petitioning shareholders. Thirty-one of those states include 'oppression' in their statute."). See, e.g., N.Y. BUS. CORP. LAW § 1104-a(1) (McKinney 2003) (permitting petitions for judicial dissolution of a corporation where "[t]he directors or those in control of the corporation have been guilty of illegal, fraudulent or oppressive actions toward the complaining shareholders"); TEX. BUS. CORP. ACT ANN. art. 7.05(A) (Vernon 2003) (permitting the appointment of a receiver where "acts of the directors or those in control of the corporation are illegal, oppressive or fraudulent"). The Deleware Supreme Court, on the other hand, has refrained from creating special judicial protections for minority shareholders in close corporations. See Nixon v. Blackwell, 626 A.2d 1366, 1380-81 (Del. 1993).

144. See 1 O'NEAL \& THOMPSON, supra note 37, at ix ("Even in the absence of statute, a few courts have granted [the dissolution] remedy under their equitable powers.").

145. See ElizABETH J. Boros, MINORITY SHAREHOLDERS' REMEDIES 111-65 (1995) (describing oppression/unfair prejudice remedies in English and Australian law); Brian Cheffins, The Oppression Remedy in Corporate Law: The Canadian Experience, 10 U. PA. J. INT'L BUS. L. 305 (1988) (describing the oppression remedy in Canadian law).

146. 15 PA. CONS. STAT. ANN. $\$ 1767$ (a)(2) (West 1995); see, e.g., Kevin B. Scott, Minority Shareholder Rights: Pennsylvania 's Custodian Statute, 65 PA. B. ASS'N Q. 97,97 (1994).

147. Cf. EASTERBROOK \& FISCHEL, supra note 15, at 228-52 (1991) (critiquing mandatory legal rules designed to protect shareholders in close corporations).

148. Indeed, the oppression doctrine is justified on the ground that the minority shareholder cannot protect herself by contract. See Douglas K. Moll, Reasonable Expectations v. Implied-inFact Contracts: Is the Shareholder Oppression Doctrine Needed?, 42 B.C. L. REV. 989 (2001) (arguing that the oppression doctrine is justified because contract law fails to protect adequately minority investors' reasonable expectations).

149. Contractarians might explain this state intrusion on private ordering as simply enforcing the bargain that the shareholders would have struck had they actually negotiated the point. But if indeed a hypothetical bargain should be sufficient to garner the enforcement power of the state, why does contract law generally find such bargains unenforceable? Perhaps the contractarians' underlying claim is not the rightness of corporate law, but the wrongness of contract law (because it often fails to enforce hypothetical bargains). A true contractarian victory should do away with 
Carolina Supreme Court noted the self-help possibility but excused the minority shareholder for not protecting himself, explaining: "Some may argue that the minority shareholder should have bargained for greater protection before agreeing to accept his minority shareholder position in a close corporation. However, the practical realities of this particular business situation oftentimes do not allow for such negotiations." 151 Not only are negotiations not required, but the claim for oppression also may not be yielded by the minority shareholder in a negotiation at the time the investment is made, as the oppression claim is mandatory law. ${ }^{152}$

\section{Cumulative Voting}

It was Lani Guinier's invocation of corporate cumulative voting for the political context that earned her the label "quota queen." "I53 In corporate law, however, cumulative voting is a venerable device for minority protection, though it has fallen far from its zenith. In citing this procedure, Professor Guinier was only retracing corporate law's own borrowing from politics.

The origins of cumulative voting ${ }^{154}$ in corporate law lie in the political writings of John Stuart Mill. Seeking to ensure that a minority would be "heard" in a democracy, ${ }^{155}$ Mill recommended a number of voting procedures that would help guarantee minority representation in a legislature. He described, for instance, a procedure whereby "the elector retained his three votes, but was at liberty to bestow them all upon the same candidate."156 While Mill's proposals about minority political classes were circulating, minority shareholders were suffering from "publicized sagas of corporate freebooting" including most conspicuously those of Drew, Fisk,

most corporate law altogether, except perhaps as a species of contract and property law. Even offthe-shelf default rules could be supplied by the private market.

150. 307 S.E. $2 d 551$ (N.C. 1983).

151. Id. at 558 .

152. See Edward B. Rock \& Michael L. Wachter, Waiting for the Omelet To Set: MatchSpecific Assets and Minority Oppression in Close Corporations, 24 J. CORP. L. 913, 924 (1999) ("These various doctrines have proved difficult to contract out of.").

153. See supra note 11.

154. "Cumulative voting is a means devised to protect minorities by providing a method of voting which assures to a minority, if it is sufficiently purposeful and cohesive, representation on the board of directors to an extent roughly proportionate to the minority's size." CTS Corp. v. Dynamics Corp. of Am., 481 U.S. 69, 86 n.11 (1987) (citation omitted). The mechanism is as follows: "[E]ach shareholder possesses a number of votes equal to the number of his or her shares multiplied by the number of directorships to be filled, but can distribute the product among candidates as he or she chooses." 2 JONATHAN R. MACEY, MACEY ON CORPORATION LAWS $\S 13.16[\mathrm{~B}]$ (Supp. 1999).

155. JoHn Stuart Mill, CONSIDERations On RePresentative Government 127 (E.P. Dutton \& Co. 1928) (1861).

156. Id. at 133 . 
and Gould in the Erie Railroad. ${ }^{157}$ These circumstances help explain how cumulative voting came to be introduced to corporate governance through state constitutional amendments. Prominent at the Illinois constitutional convention of 1870 was Joseph Medill, an "ardent advocate" of John Stuart Mill's principle of minority protection. ${ }^{158}$ Medill helped persuade the convention to amend the state constitution to require cumulative voting both for representatives to the state house and for corporate directors.

In corporate law, cumulative voting became a method by which minorities could not only be heard, but also could see, with their elected representatives acting as a "window into the boardroom." 159 Even today, the justifications for cumulative voting in corporate law track those originally offered by Mill in favor of minority representation in government. ${ }^{160}$

The "high water mark" of cumulative voting occurred in the late 1940s, when twenty-two states constitutionally mandated cumulative voting in corporations. ${ }^{161}$ Today, only six states provide for cumulative voting for directors in their constitutions, and none requires it. ${ }^{162}$ Every state permits cumulative voting for directors; ${ }^{163}$ but now that it is no longer mandatory, this most well-known of minority protection devices has proven unpopular, with few modern corporations choosing the device. ${ }^{164}$ It seems that, left to fend for themselves, minorities have either determined that cumulative voting was an unnecessary protection or have failed to persuade corporations to adopt it.

157. Charles M. Williams, Cumulative Voting FOR Directors 21 (1951).

158. Whitney Campbell, The Origin and Growth of Cumulative Voting for Directors, 10 BUS. LAW. 3, 4 (1955).

159. See CHOPER ET AL., supra note 55, at 599; Harlowe E. Bowes \& Ledlie A. De Bow, Cumulative Voting at Elections of Directors of Corporations, 21 MINN. L. REV. 351, 353 (1937) (explaining that cumulative voting enables minority interests "to 'obtain direct contact with the business of the corporation, and its management, and observe the conduct of the corporate officers"' (quoting State ex rel. Price v. DuBrul, 126 N.E. 87 (Ohio 1919))). See generally CLARK, supra note $29, \S 9.1 .3$ (summarizing arguments for and against cumulative voting).

160. Campbell, supra note 158, at 14 ("The arguments presented by those who favor cumulative voting for directors are similar to those originally made by John Stuart Mill in writing on the desirability of minority representation in government.").

161. See Jeffrey N. Gordon, Institutions as Relational Investors: A New Look at Cumulative Voting, 94 COLUM. L. REV. 124, 145 (1994).

162. ARIZ. CONST. art. XIV, $\S 10$; IDAHO CONST. art. XI, $\S 4$; ILL. CONST. Transition Schedule $\S 8$ (1970); Mo. ConST. art. XI, $\S 6$; N.D. ConST. art. XII, §8; W. VA. CONST. art. XI, $\S 4$.

163. See CTS Corp. v. Dynamics Corp. of Am., 481 U.S. 69, 86 n.11 (1987).

164. STEPHEN M. BAINBRIDGE, CORPORATE LAW AND ECONOMICS 445-56 (2002) (arguing that cumulative voting has grown increasingly unpopular because of its tendency to create an adversarial board controlled by majority factions); FRANKLIN A. GEVURTZ, CORPORATE LAW § 5.2.1.A, 481-86 (2000) (maintaining that cumulative voting is ineffective unless minority shareholders control a substantial percentage of outstanding voting stock). 


\section{Appraisal}

The disaffected minority shareholder faced with an unappealing corporate reorganization finds some refuge in state corporate codes. Rather than suffer the consequences of continuing her investment or being cashed out at an unattractive price, the shareholder can seek to divest herself of the investment at a judicially appraised value. The corporate codes of every state grant shareholders this right of appraisal in the event of certain fundamental changes. ${ }^{165}$

The right is, however, severely compromised. Procedural requirements and, most importantly, a bar against class actions render appraisal a remedy generally not worth the cost of its exercise, except for minority investors with very valuable stakes. About half of the states, including Delaware, deny an appraisal right to shareholders in public companies, presumably on the theory that such shareholders can find liquidity at a fair price in the public market. ${ }^{166}$ In addition, some states offer appraisal as the exclusive option of the aggrieved shareholder, thereby denying the shareholder the right to enjoin an unfair transaction and retain her investment.

Despite its imperfect protection, the appraisal right demonstrates corporate law's view that independent assessments may be necessary from time to time. Rather than leave the minority investor to the mercy of the bargain struck upon entry, it provides her with a statutory right to invoke a judicial inquiry into fair price.

\section{Securities Regulation}

The elaborate framework regulating securities offerings, too, can be understood principally as a means of protecting minority investors from exploitation by managers and controlling shareholders. ${ }^{167}$ While securities law protects rich and poor alike-the institutional investor alongside the middle class retiree-it is motivated largely by the concern that controlling persons, be they controlling shareholders or managers, may exercise their

165. Robert B. Thompson, Exit, Liquidity, and Majority Rule: Appraisal's Role in Corporate Law, 84 GEO. L.J. 1, 9 (1995); see also James Vorenberg, Exclusiveness of the Dissenting Stockholder's Appraisal Right, 77 HARV. L. REV. 1189, 1189 (1964) (noting that all states but West Virginia grant appraisal rights).

166. See Thompson, supra note 165 , at 29 . This public market exception to the appraisal right rests on the efficient market hypothesis: The public market is presumed to offer a fair opportunity for exit. This presumption is contrary to Delaware jurisprudence, which, as I noted earlier, denies the accuracy of the prevailing market price as a signifier of "intrinsic" value.

167. See Coffee, supra note 18 , at 652 (noting the special focus of the federal securities laws on constraining controlling shareholders). 
power to garner disproportionate shares of corporate wealth at the expense of minority shareholders. ${ }^{168}$

The fundamental mandate of American securities regulationdisclosure of material information-serves principally to benefit minority investors. Controlling shareholders, by virtue of their control, have other avenues to obtain information, including, for example, their representatives on the board of directors. And directors and officers, of course, are presumed to be well aware of corporate information. Periodic reporting, ${ }^{169}$ proxy communications, ${ }^{170}$ and prospectus delivery requirements ${ }^{171}$ seek to keep the minority investor duly informed about her investment. The goal is not only to enhance decisionmaking ability, but also more specifically to avoid manipulation of investors by corporations or traders. John Coffee identifies the following constraints on controlling shareholders in American securities law:

(1) [I]ts ownership disclosure rules deny them the veil of anonymity by requiring a transparent ownership structure pursuant to section 13(d) of the Exchange Act;

(2) its insider trading rules restrict (with criminal penalties) their ability to purchase or sell based on material, nonpublic information;

(3) its tender offer rules assure all shareholders an equal opportunity to participate in any tender offer for their shares;

(4) its continuous disclosure system generally requires timely disclosure of material developments by the issuer or controlling shareholders; and

(5) its "going private" rules deny controlling shareholders the practical ability to squeeze out the minority at an unfairly low price. $^{172}$

In crafting such a defensive regime, securities regulation responds to experience not only with the "gullibility of buyers" of securities, ${ }^{173}$ but also with the devious schemes of manipulators. The recent innovation of "plain

168. Securities regulation, of course, extends to debt securities as well as equity securities. I do not mean to characterize all of securities regulation as having a single-minded focus on minority shareholder protection.

169. See Securities Exchange Act of 1934 § 14, 15 U.S.C. $\S 78 \mathrm{~m}(2000)$.

170. Section 15 of the Securities Exchange Act sets forth the proxy disclosure requirements. 15 U.S.C. $\$ 78 \mathrm{n}$.

171. See Securities Act of $1933 \S 5,15$ U.S.C. $\S 77$ e.

172. Coffee, supra note 18 , at $690-91$ (footnote omitted).

173. LOUIS LoSS \& JOEl SEligman, FUNDAMENTALS OF SECURITIES REgUlation 1 (4th ed. 2001). 
English" in disclosure reflects a concern that buyers might be misled or even duped by impenetrable prose. ${ }^{174}$ The paternalistic concern with protecting investors from making misinformed decisions becomes clear in the circumstances where securities law reduces its demands. At times, securities law relaxes its mandates for entities better able to secure their own position in the corporation without state assistance. Entities identified as "accredited investors"175 or "qualified institutional buyers"176 may invest with fewer mandatory protections. There are even "portals" through which only qualified investors may trade. ${ }^{177}$ Securities law eases its requirements on the theory that some minority investors are better able than others to fend for themselves. ${ }^{178}$ For sophisticated minority investors, the presumption of peril can be relaxed. ${ }^{179}$

The fact that much of securities regulation is mandatory, not permissive, demonstrates the extent to which the law refuses to rely on contract alone to reach its goals of investor protection. ${ }^{180}$ Prominent recent scholarship questions this mandatory nature, suggesting that issuer choice of regulatory regime might prove a more efficient system of investment. ${ }^{181}$

174. Plain English Disclosure, Exchange Act Release No. 39,593, 63 Fed. Reg. 6370 (Feb. 6 , 1998) (codified at 17 C.F.R. pts. 228-30, 239, and 274) (explaining the need for a plain English requirement based on the fact that prospectuses today are difficult to understand because of unnecessarily complex language and stilted jargon).

175. Rule 501(a)(5) under Regulation D of the Securities Act defines any "natural person whose individual net worth . . exceeds $\$ 1,000,000$ " to be an "accredited investor." 17 C.F.R. $\$ 230.501(\mathrm{a})(5)(2003)$. Regulation D exempts from registration offers that are extended to a limited number of investors. Id. $\S \S 230.504-.506$.

176. Rule 144A provides a safe harbor from the registration requirements of the Securities Act for resales of certain securities among "qualified institutional buyers" (institutions that own or manage at least $\$ 100$ million of securities). Id. $\S 230.144 \mathrm{~A}$.

177. The portal market permits secondary trading of unregistered securities in transactions exempt from registration pursuant to SEC Rule 144A. See NAT'L ASS'N OF SEC. DEALERS, NASD MANUAL $\S 5322$ (2001).

178. Under Regulation D, while "accredited investors" are presumed to be sophisticated investors, nonaccredited investors must have "such knowledge and experience in financial and business matters that they are capable of evaluating the merits and risks of the prospective investment." 17 C.F.R. $\$ 230.506$ (b)(2)(ii). Similarly, Rule 144A justifies the relaxation of requirements for the "investment sophistication" of the qualified institutional buyers. Resale of Restricted Securities, Securities Act Release No. 6862, [1989-1990 Transfer Binder] Fed. Sec. L. Rep. (CCH) ๆ 84,523 (Apr. 23, 1990).

179. Of course, even sophisticated investors may not always be able to penetrate the dense prose of disclosure documents. The noted (and certainly sophisticated) billionaire investor Warren Buffett implies that he too will be a beneficiary of plain English requirements: "For more than forty years, I've studied the documents that public companies file. Too often, I've been unable to decipher just what is being said ...." Warren E. Buffett, Preface to OFFICE OF INVESTOR EDUC. \& Assistance, SEC, A Plain ENGlish HaNDBook: How To Create Clear SEC Disclosure DOCUMENTS 1 (1998).

180. But see Chander, Diaspora Bonds, supra note 5, at 1081-86 (noting recent case law permitting investors to opt out of the securities laws in certain circumstances despite an apparent statutory command to the contrary).

181. See, e.g., Stephen J. Choi, Promoting Issuer Choice in Securities Regulation, 41 VA. J. INT'L L. 815 (2001); Stephen J. Choi \& Andrew T. Guzman, Portable Reciprocity: Rethinking the International Reach of Securities Regulation, 71 S. CAL. L. REV. 903 (1998); Roberta Romano, 
Yet there is little likelihood that, in the face of the recent catastrophic collapses of public companies, there will be a relaxation of the securities regime. Indeed, the securities market crisis for which Enron and WorldCom serve as synecdoches led to the adoption of legislation that heightens disclosure standards. ${ }^{182}$ Finally, the complexity of the securities market and the opaqueness of brokerage transactions have led even contractarians to endorse retaining mandatory regulation of securities exchanges and brokers. ${ }^{183}$

One might have expected to find in corporate law the unimpeded values of the market- of private contracting and property rights. Instead, the above study reveals that corporate law does not yield entirely to the operation of the market.

Rather, corporate law is largely motivated by fear of the abuse of control by controlling shareholders or controlling management. It recognizes the differential power relationships that exist within the corporate structure and seeks to manage them in a way that is ultimately beneficial to society. It is to the elaboration of this insight in the constitutional realm to which I now turn.

\section{LIKE MINORITY SHAREHOLDERS}

The civil rights project has expanded by analogy to earlier struggles, with the recent women's rights, gay rights, and disabled rights campaigns modeling themselves explicitly on the earlier African-American rights campaign. But with the recent judicial assault on affirmative action, "like race" arguments have fallen out of favor, criticized as liable to hurt, not help, the call for substantive equality. ${ }^{184}$ The discussion above in Part I demonstrates the existence of a vibrant part of American law that protects minorities-namely, minority shareholders. In this Part, I show that civil rights struggles could proceed on an alternative analogy by turning to

Empowering Investors: A Market Approach to Securities Regulation, 107 YALE L.J. 2359 (1998) [hereinafter Romano, Empowering Investors]; Roberta Romano, The Need for Competition in International Securities Regulation, 2 THEORETICAL INQUIRIES L. 387 (2001).

182. See Sarbanes-Oxley Act of 2002, Pub. L. No. 107-204, 116 Stat. 745 (to be codified in scattered sections of $11,15,18,28$, and 29 U.S.C.).

183. See, e.g., Romano, Empowering Investors, supra note 181, at 2369 ("The federal securities regime regarding the regulation of securities markets and market professionals who broker transactions between investors and issuers is excluded from the proposed market approach.").

184. See Janet E. Halley, "Like Race" Arguments, in JUdith BUTLER ET AL., What's LefT OF THEORY? 40 (2000). 
minority shareholders, a genus of minority that has heretofore escaped the attention of civil rights scholars. An examination of the motivations underlying law's solicitude towards minority shareholders reveals a concern for fairness and capital formation that has direct application to the issue of affirmative action.

But is not race different from shareholding? Yes, of course. I do not claim that minority status per se necessitates legal protection. My goal here is not "to vary the . . level of abstraction to make it come out right." ${ }^{\text {"185 I }}$ thus consider the differences between minority races and minority shareholders to see whether the differences justify law's divergent approaches to the two.

While consideration of the different contexts in which minorities arise is necessary, it must be remembered that the burden of the argument might just as easily be said to fall on those who would maintain divergent approaches. It would seem that the default rule should favor like treatment of minorities - regardless of whether they are minorities in constitutional or corporate law. Indeed, the Supreme Court itself has announced a principle of "consistency," though it applies this principle only with respect to governmental racial classifications. ${ }^{186}$ Those who endorse different treatment must be prepared to defend it. Of course, I defend here another kind of difference-between minorities and controlling persons-while at the same time proposing a general, unified theory of legal treatment of minorities.

My claim for a level of universality finds support in a somewhat surprising quarter. The Chicago economics tradition-articulated most forcefully by Gary Becker ${ }^{187}$ - takes as its foundational principle that there is a universal science that can encompass all human relations, from the economic to the familial. Such a science becomes possible because of the belief that human behavior has a consistency across operational realms. ${ }^{188}$ My own claim for transcendence is more modest, though it too is ultimately behavioral. I suggest that both corporate law and constitutional law address a similar dynamic - the exercise of power by controlling groups to benefit themselves at the expense of minorities. This Part thus concludes with a discussion of power in both the corporate and constitutional spheres, drawing upon the work of critical race scholars and corporate law theorists.

185. JOHN HART Ely, DEMOCRACY AND DistRust: A THEORY OF JUDICIAL REVIEW 61 (1980).

186. See Adarand Constructors, Inc. v. Pena, 515 U.S. 200, 223-24 (1995) (describing "consistency" as one of "three general propositions with respect to governmental racial classifications").

187. See GARY S. BeCKer, The ECONOMIC APPROACH to Human Behavior (1976).

188. Id. at 14. The behavioral law and economics movement-which recognizes the irrationalities and biases in human behavior-substantially complicates the law and economics project. 
I find in both an understanding of power that resonates with the theories of Michel Foucault. My underlying argument is that the primary project of law is to regulate the exercise of power.

While affirmative action programs generally seek to promote opportunities for women as well as people of minority races, I will speak generally of race rather than of gender. But the analogy between minority shareholders and women may also be quite instructive. For example, my description of how smaller groups can come to dominate larger ones (what I refer to as the "majority-minority" issue) ${ }^{189}$ resonates especially well with the condition of women in society. At the same time, differences between race and gender should not be minimized. I also do not consider here the status of sexual minorities, though I anticipate that much useful work could be done to relate the status of such minorities to the structure of corporate law. ${ }^{190}$ Additionally, affirmative action programs occasionally turn on economic status, ${ }^{191}$ but I do not apply my analysis directly to subordination by poverty, though poverty is often the basis for subordination. ${ }^{192}$ I also do not consider minority status based on religion, age, weight, and other such characteristics, though again such characteristics might form the basis for subordination and remediation. ${ }^{193}$

In contrasting aspects of corporate and constitutional law, I follow a long and renowned tradition of intradisciplinary work. ${ }^{194}$ Such intradisciplinarity seems especially appropriate to law, a discipline that relies on analogical reasoning. Differences between legal domains must be justified by differing circumstances or objectives. Intradisciplinarity transfers theories, practices, and technologies across legal domains. ${ }^{195}$ More

189. See infra Section III.C.

190. Martha Ertman's work relating marriage law to the law on close corporations offers an important example of such comparative studies. See Martha M. Ertman, Marriage as a Trade: Bridging the Private/Private Distinction, 36 HARV. C.R.-C.L. L. REV. 79 (2001).

191. The program at issue in Adarand, for example, made special provision for “"economically disadvantaged"” persons. 515 U.S. at 209 (quoting 49 C.F.R. $§ 23.69$ (1994)).

192. See CHARles R. LAWRENCE III \& MARI J. MATSUDA, WE WON'T Go BACK: MAKING THE CASE FOR AFFIRMATIVE ACTION 178-202 (1997).

193. See ROBERT POST, Prejudicial Appearances, in PREJUdicial APPEARANCES 1, 10-11 (2001) (discussing discrimination based on immutable traits, such as sex, and mutable traits, such as obesity).

194. See, e.g., GRANT GILMORE, THE DEATH OF CONTRACT 87 (1974) (considering the intersection of torts and contracts); Guido Calabresi \& A. Douglas Melamed, Property Rules, Liability Rules, and Inalienability: One View of the Cathedral, 85 HARV. L. REV. 1089 (1972) (describing property and liability rules and inalienability, and revealing the underlying goals that property, tort, and criminal law share); Duncan Kennedy, Form and Substance in Private Law Adjudication, 89 HARV. L. REV. 1685, 1686 (1976) (observing that contracts scholarship is "full of insights that seem to beg for application beyond the narrow compass within which their authors developed them").

195. See Kathleen M. Sullivan, Foreword: Interdisciplinarity, $100 \mathrm{MICH}$. L. REV. 1217, 1221 (2002) (arguing that interdisciplinary work in law improves knowledge about law and legal institutions, advances the practice of law and quality of legal rules, and benefits other disciplines). 
fundamentally, it helps reveal law's larger projects and, at times, law's hypocrisies.

\section{A. Managing Power}

While now often associated with radical thought, legal theories based on power have a long provenance in corporate law. In their classic text on the modern corporation, Berle and Means speak of "power and its regulation."196 Berle spent much of his later life thinking about the "problem of power." 197 His interest might even be called an obsessionwitness his four books focused on the subject, capped in 1969 with a book titled simply Power. ${ }^{198}$ Berle, John Kenneth Galbraith writes, "over a long life concerned himself more deeply than any other American writer with the nature of power." 199

Berle traces the "changing location of power" in the corporation. ${ }^{200}$ But while he carefully catalogues the characteristics of power, he devotes few pages to the question of how power might be constrained. ${ }^{201}$ Scholars, judges, and legislators have, however, taken up the baton in crafting the technology of minority shareholder protection in the face of corporate power holders. These reformers located power and sought to prevent its abuse. People such as Hodge O'Neal meticulously studied how, for example, shareholders might be oppressed within the close corporation ${ }^{202}$ and identified strategies to counter such oppression. ${ }^{203}$ The mechanisms of corporate law are often explicitly sensitive to power relations, from then-Judge Cardozo's observation that "[a] dominating influence may be exerted in other ways than by a vote" 204 to the assumption of the securities laws that controlling shareholders and insiders must be treated differently from others. ${ }^{205}$

We must ask here the crucial question: Why does corporate law focus on power? The answer is that its focus on power is necessary to further its

196. BERLE \& MEANS, THE MODERN CORPORATION 1932, supra note 41, at 353.

197. See, e.g., ADOLF A. BERLE, JR., POWER WITHOUt PROPERTY: A NEW DEVELOPMENT IN AMERICAN POLITICAL ECONOMY 79 (1959).

198. Adolf A. Berle, JR., ECONOMiC PoWer AND the Free Society (1957); Adolf A. BERLE, JR., POWER (1969) [hereinafter, BERLE, POWER]; BERLE, supra note 197; ADOLF A. BERLE, JR., THE THREE FACES OF POWER (1967).

199. JOHN KeNNETH GalbRAITH, THE ANATOMY OF POWER 48 (1983).

200. BERLE, supra note 197, at 69.

201. See, e.g., id. at 87-93 (offering, as possible limits on corporate power, pluralism, the need for profits, corporate conscience and prestige loss, and periodic government intervention).

202. See, e.g., F. HOdGE O'NEAL \& JORDAN DERWIN, EXPULSION OR OPPRESSION OF BUSINESS ASSOCIATES: SQUEEZE-OUTS IN SMALL ENTERPRISES 4-5, 41-60 (1961).

203. See, e.g., id. at 170-90.

204. Globe Woolen Co. v. Utica Gas \& Elec., Co., 121 N.E. 378, 379-80 (N.Y. 1918).

205. See supra notes $170-172$ and accompanying text. 
goals of capital formation and fairness. ${ }^{206}$ John Coffee sums up my corporate law claim pithily: “'[S]trong' regulation permits 'weak' owners." 207

Power, of course, is not alien to constitutional law. The federal government, we know, is one of enumerated powers; their exercise is checked through the separation of powers. Yet, when constitutional law turns its gaze to educational and workplace opportunities, it turns a blind eye to power. The current constitutional understanding is bitingly summarized by Kimberlé Crenshaw: "After all, equal opportunity is the rule, and the market is an impartial judge; if Blacks are on the bottom, it must reflect their relative inferiority. $" 208$ This understanding is indifferent to power relations; any relations of domination or oppression are only products of marketplace judgments, which are themselves impartial.

This view is, of course, the target of feminist and other critical scholars. For them, the marketplace in education and labor cannot be understood without accounting for relations of domination and subordination. Critical race scholars seek to foreground racial subordination in their examination of the law, ${ }^{209}$ while feminists foreground sexual power as central to understanding legal relations. ${ }^{210}$ Both sets of scholars reject theories of law that seek to combat only discrimination, finding them insufficient for the protection of minority groups. ${ }^{211}$ Where antidiscrimination focuses on the formal evenhandedness in the "allocative process," the antisubordination principle favored by critical theorists requires consideration of the power relations in operation. Racial and gender justice, they argue, requires a more substantive principle of equality. This is because the existing hegemony operates so convincingly as to make its operation invisible: As Mari

206. See infra Section II.B.

207. Coffee, supra note 18 , at 648 .

208. Kimberlé Williams Crenshaw, Race, Reform, and Retrenchment: Transformation and Legitimation in Antidiscrimination Law, 101 HARV. L. REV. 1331, 1380 (1988).

209. See, e.g., DERRICK BELL, AND WE ARE NOT SAVED: THE ElUSIVE QUEST FOR RACIAL JUSTICE 26-50 (1987).

210. See, e.g., CATHARINE A. MACKINNON, FEMINISM UNMODIFIED: DISCOURSES ON LIFE AND LAW 32-45 (1987).

211. See, e.g., Ruth Colker, Anti-Subordination Above All: Sex, Race, and Equal Protection, 61 N.Y.U. L. REV. 1003, 1035-45 (1986); Owen M. Fiss, Groups and the Equal Protection Clause, 5 PHIL. \& PUB. AfF. 107, 129-46 (1976); Charles R. Lawrence III, Foreword: Race, Multiculturalism, and the Jurisprudence of Transformation, 47 STAN. L. REV. 819, 822-25 (1995). Owen Fiss differentiates between antidiscrimination and antisubordination (in the context of gender) as follows:

The antisubordination principle... is not confined to the regulation of the type of allocative process that is the special focus of the antidiscrimination principle. It reaches any practice or institution that disadvantages women, and accordingly has been used to support increases in the availability of birth control and child care facilities, as well as requiring employers to provide parental leave.

Owen M. Fiss, What Is Feminism?, 26 ARIZ. ST. L.J. 413, 419 (1994). 
Matsuda writes, "Power at its peak is so quiet and obvious in its place of seized truth that it becomes, simply, truth rather than power."212

This critical view coincides in an important way with that of corporate law, which also requires an accounting of power relations in generating legal decisions. Both corporate law and critical scholarship recognize, often implicitly, the inability of market mechanisms alone to avert minority abuse by those in power. My goal here is not to assert the truth value of these critical claims about race or gender, but only to assert that they are the kind of inquiries relevant to legal decision. Moreover, they are the kind of inquiries-about domination, subordination, and oppression-that corporate law routinely undertakes.

It does not follow that all claims for subordination are equally worthy. Some affirmative action programs may have overreached, covering groups that did not need them under the circumstances, while other affirmative action programs may have underreached. The determination of which minorities deserve affirmative protection must be both careful and contextspecific. ${ }^{213}$

It is only after the identification of power and domination that corporate law and critical scholarship part company. Where critical scholars aspire to the destruction of hegemony, ${ }^{214}$ corporate law aspires only to its management. Corporate law recognizes the inevitability of power imbalances. In response to the possible self-dealing of controlling shareholders and management, corporate law seeks to establish other resources of power in minority shareholders.

The paramount resource is information. ${ }^{215}$ Like the Benthamite Panopticon-the prison in which the warden can see all that passes ${ }^{216}$ - the public corporation configures minority shareholders as mini-wardens. As Foucault writes, "[T] he major effect of the Panopticon [is] to induce in the inmate a state of conscious and permanent visibility that assures the automatic functioning of power."217 Securities regulation's strict disclosure requirements, ${ }^{218}$ the Schedule $13 \mathrm{G}$ reporting requirements for owners of more than five percent of outstanding shares, ${ }^{219}$ inspection rights, and the

212. Mari J. Matsuda, Pragmatism Modified and the False Consciousness Problem, $63 \mathrm{~S}$. CAL. L. REV. 1763, 1765 (1990).

213. See infra Section II.D.

214. See, e.g., DUNCAN KENNEDY, LEgal EDUCATION AND THE REPRODUCTION OF HIERARCHY: A POLEMIC AGAINST THE SYSTEM (1983).

215. See MiCHEL FouCAult, Two Lectures, in POWER/KNOWLEDge: SELECTED INTERVIEWS AND OTHER WRITINGS 1972-1977, at 78 (Colin Gordon ed. \& Colin Gordon et al. trans., Pantheon Books 1980) (1972) (relating knowledge to power).

216. JeREMY BENTHAM, The PANOPTICON WRITINGS (Miran Bozovic ed., Verso 1995) (1791).

217. Michel Foucault, Discipline AND PUNiSh 201 (Alan Sheridan trans., Pantheon Books 1977) (1975).

218. E.g., 15 U.S.C. $\S 78$ p(a) (2000).

219. Id. $\S 78 \mathrm{~m}(\mathrm{~g})$. 
derivative suit ${ }^{220}$ help to create a disciplinary power that counters that of controlling shareholders or management. ${ }^{221}$

In a broad sense, affirmative action can be understood in a similar vein. The promotion of education and workplace opportunities among the less powerful in society is designed precisely to create resources of power in this part of the community. Both education and employment empower individuals to help protect themselves against exploitation by others.

Foucault observes that disciplinary technologies such as the Panopticon have been operationalized in multiple domains; he asks, "Is it surprising that prisons resemble factories, schools, barracks, hospitals, which all resemble prisons?"222 We might similarly ask: Is it surprising that corporations in some ways resemble constitutional domains?

\section{B. Motivations}

In order to examine whether the analogy between minority shareholders and minority races holds, it is important to ask why corporate law protects minority shareholders. I identify two reasons: a desire for fairness and the promotion of capital formation. I note at the outset that it is possible to collapse the two goals into one: Fairness might be described as a purely instrumental device, designed ultimately to promote capital formation. This does not defeat my reasoning, as I rely principally on capital formation, not fairness, to draw my analogy. In Part III, I complete my argument by demonstrating that the goal of capital formation might also justify minority protection in the constitutional context.

\section{Fairness}

The concern for fairness to minority shareholders has a long history in corporate law. Majority rule and board control are tempered by doctrines designed to deter unfairness toward minority shareholders. Nineteenth-century conceptions of the corporation sought to limit the voting power of large shareholders. ${ }^{223}$ At that time, major changes required a unanimous vote, allowing minority shareholders to veto significant changes antithetical to their interests. As we have seen, cumulative voting

220. See supra notes 73-77 and accompanying text.

221. 15 U.S.C. $\$ 78 \mathrm{u}-4$ (a).

222. FoUCAULT, supra note 217 , at 228.

223. David L. Ratner, The Government of Business Corporations: Critical Reflections on the Rule of "One Share, One Vote," 56 CORNELL L. REV. 1, 6-11 (1970). Ratner goes on to argue for the radical proposal that any person, even without equity ownership, should receive an equal vote in corporate elections. $I d$. at 52. 
for corporate boards stemmed from notions of fairness to minorities described by John Stuart Mill. ${ }^{224}$

Even today, the fiduciary duties that make up much of the law of corporate governance rely centrally on notions of "fairness." In interested shareholder transactions, for example, the controlling shareholder bears the burden under Delaware law of proving "inherent fairness." 225 In large part, the fiduciary duty of loyalty seeks to sort out interested director transactions on the basis of fairness. ${ }^{226}$ The tests for actions like the usurpation of corporate opportunity rely on notions of fairness. Then-Chief Judge Cardozo's famous requirement of the "finest loyalty" from fiduciaries, ${ }^{227}$ though propounded in the partnership context, finds its way into the corporate realm. ${ }^{228}$ Indeed, it has survived into the new millennium, cited by the Fifth Circuit in a recent corporate law case. ${ }^{22}$ Then-Chief Judge Cardozo, we recall, called upon fiduciaries to abjure the "morals of the market place." 230 This moralistic tone-captured most succinctly in Cardozo's standard of "the punctilio of an honor the most sensitive"231 runs deep through the history of American corporate law. ${ }^{232}$ In interpreting (and inventing) corporate law, courts often look "not to the technical knowledge of economics ... but to the everyday notions of right conduct." ${ }^{, 233}$ It is fairness, not efficiency, that is typically on the lips of judges. ${ }^{234}$ Securities regulation too was founded in part on legislative perceptions of the unfairness of exploitation by controlling persons of minority investors. The Securities Act was introduced in the pages of the Harvard Law Review in 1934 as "in the main a modification of common-law deceit principles to meet the exigencies of a corporate economy." ${ }^{, 235}$ For its part, the Securities and Exchange Act of 1934 repeatedly references the need to ensure fair and

224. See supra notes $154-160$ and accompanying text.

225. Weinberger v. UOP, Inc., 457 A.2d 701, 710 (Del. 1983).

226. See, e.g., William MEADE FleTCHER ET AL., FLETCHER CYClOPEDIA OF THE LAW OF PRIVATE CORPORATIONS $\S \S 950-951$ (perm ed., rev. vol. 2002); 1 PRINCIPLES OF CORPORATE GOVERNANCE, supra note $34, \S 5.10$ (requiring that transactions between a controlling shareholder and a corporation be "fair" to the corporation).

227. Meinhard v. Salmon, 164 N.E. 545, 546 (N.Y. 1928) (Cardozo, C.J.).

228. See Robert W. Hillman, Business Partners as Fiduciaries: Reflections on the Limits of Doctrine, 22 CARDOZO L. REV. 51,69 (2000).

229. Hollis v. Hill, 232 F.3d 460, 468 n.23 (5th Cir. 2000).

230. Meinhard, 164 N.E. at 546.

231. Id.

232. William T. AlLEN \& REINIER KRAAKMAN, COMMENTARIES AND CASES ON THE LAW OF BUSINESS ORGANIZATION 7 (2003) ("For centuries, courts have used the language of moral reasoning .... [C]ourts often refer to 'fairness,' 'good faith,' 'justifiable reliance,' 'loyalty,' 'candor,' 'exploitation,' and 'penalties."').

233. Id.

234. See id. at 2 ("[C]ourts ... frequently invoke the concept of faimess in their work and rarely address the efficiency of corporate law doctrines, at least in so many words.").

235. Note, Federal Regulation of Securities: Some Problems of Civil Liability, 48 HARV. L. REV. 107, 121 (1934). 
honest markets. ${ }^{236}$ According to the Supreme Court, the goal of the Securities Exchange Act was "to achieve a high standard of business ethics in the securities industry.,"237

\section{Capital Formation}

To contractarians, the concern for fairness in corporate law seems misplaced. Easterbrook and Fischel put it nicely: "Investors are not candidates for transfers of wealth; this is not a branch of poverty law.... Questions of distribution among investors are unimportant; allocating gains to one rather than another changes relative prices but not social wealth."238 Corporate law, contractarians claim, should be structured for one immediate goal alone: efficiency. Efficiency, of course, may come at the price of distributional equity-as Easterbrook and Fischel acknowledge. To a large extent, this law and economics vision has come to dominate thinking about corporate law, in both the judiciary and the academy. As time passes, Meinhard is invoked ever more rarely in corporate law opinions. And for its part, the academy reinterprets corporate doctrines according to the dictates of the efficiency norm.

According to the contractarian reading, concerns for fairness are not about justice at all; they are about efficiency. ${ }^{240}$ Ensuring that a minority shareholder is treated "fairly" by the controlling shareholder or management encourages people to invest funds without needing to worry about expropriation. ${ }^{241}$ This is the central insight of comparative corporate governance theorists. As La Porta and his coauthors write, "Corporate governance is, to a large extent, a set of mechanisms through which outside

236. E.g., 15 U.S.C. $\S 78 \mathrm{f}(\mathrm{b})(5)$ (describing the need to "promote just and equitable principles of trade"); id. $\S 78 \mathrm{k}(\mathrm{a})(2)$ (describing the need for "fair and orderly markets"); id. $\S 78 l(b)(2)$ (describing the need to promote "fair dealing" in securities markets).

237. SEC v. Capital Gains Research Bureau, Inc., 375 U.S. 180, 186 (1963).

238. EASTERBROOK \& FISCHEL, supra note 15 , at 23.

240. Courts, however, often seem to value faimess and efficiency as separate, though related, goals. See, e.g., Cent. Bank of Denver v. First Interstate Bank of Denver, 511 U.S. 164, 188 (1994) (describing the "goals of fair dealing and efficiency in the securities markets").

241. Even advocates of corporate responsibility recognize this rationale for corporate law: Just as the Bill of Rights protects minorities from the tyranny of the majority, corporate law sets limits upon how far a majority may impose its will upon the minority. And it is essential that corporate law do so. Some level of protection is necessary to encourage persons to pool their capital in an incorporated venture.

Douglas M. Branson, Corporate Governance "Reform" and the New Corporate Social Responsibility, 62 U. PITT. L. REV. 605, 621 (2001). 
investors protect themselves against expropriation by the insiders." ${ }^{242}$ And by "insiders," they mean "both managers and controlling shareholders." 243

The theory underlying the Berle-Means modern corporation is that large scale enterprise needs to pool equity capital from many people who will cede working control over that capital. ${ }^{244}$ Protections against expropriation-and, equally important, protections regarding the fair division of potential gains-help lead capitalists to part with control over their capital. The need to protect minority shareholders exists not only in large corporations, but also in small ones. As Hodge O'Neal writes, in the case of close corporations: "[A] potential source of much-needed risk capital for small business enterprises is threatened by the prevalence of squeeze-outs." 245

\section{Differences}

All this does not establish my claim. Even if the reasons for minority shareholder protection are applicable to minority racial protection, the differences between the domains of shareholding and race may yet disrupt my syllogism. Consider the following differences: (1) a special concern for protecting property rights; (2) the different American histories of corporations and of racism; (3) the difference in the exit option for shareholders and citizens; and (4) the notion that race-based dynamics, unlike corporate dynamics, are too amorphous to meet the strict demands of law. But locating differences does not itself mandate different treatmentthe question remains whether the difference is salient. Indeed, I argue below that none of these differences justifies the sharply divergent approaches taken in the law.

First, protecting minority shareholders serves to protect property rights, but property rights may also be enhanced by minority racial protection. The goal of protecting existing property rights is often emphasized at the expense of the more efficiency-minded goal of increasing societal wealth. For its part, corporate law refuses the narrow-minded protection of existing wealth and seeks instead to spur capital formation. Property rights might ultimately be made more robust through legal efforts to enlarge the group of people holding property.

242. La Porta et al., supra note 18 , at 4.

243. Id.

244. BERLE \& MEANS, THE MODERN CORPORATION 1967, supra note 41, at 2 ("In its new aspect the corporation is a means whereby the wealth of innumerable individuals has been concentrated into huge aggregates and whereby control over this wealth has been surrendered to a unified direction.").

245. 1 O'NEAL \& THOMPSON, supra note 37, § 1:04. 
Second, while history certainly helps explain why the law bears the contours it bears, one might have expected history to produce an upside-down result: more protection for minority races and less for minority shareholders. This is because the tragic history of racism should imply an increased obligation to ensure substantive equality today. ${ }^{246}$ If history is to be the guide, then the debt accumulated toward minority races through a cruel history of racism and colonialism should mandate significant protections for minority races.

The availability of exit differentiates the corporate and political spheres. ${ }^{247}$ While a shareholder in a publicly-held corporation can leave easily by liquidating her position, a citizen has stronger ties that make exit far more difficult. ${ }^{248}$ But, again, this difference should only heighten the need to protect minorities in the political realm. Political minorities, unable to escape oppression easily, exist at the mercy of those in control. Indeed, it is precisely this concern that leads corporate law to heighten its concerns for minorities - the limited liquidity of shareholdings in a close corporation causes corporate law to scrutinize such domains especially closely for evidence of oppression. Analogously, because those in control in politics need not fear minority flight, they can set the terms of their relationship with the minority to maximize exploitation. Any party who lacks the ability to walk away from a proposed deal stands to lose the bulk of any gains from trade. What's more, while scholars have long focused on options for exit, conditions of entry may be as significant-and work again in favor of legal solicitude for racial minorities. While persons generally enter a corporation upon making a relatively free choice, persons generally enter nation-states without making a choice. Even immigrants face severe restrictions on their choice, whether it be the coercion of war or poverty leading them to leave home or the hurdles of immigration laws in potential host states. ${ }^{249}$ The weaker voluntariness of entry in political society should lead us to heightened concern for members of polities than for members of corporations-either because of the moral valence of choice itself or

246. For a strong exposition of this claim, see RANDALL ROBINSON, THE DEBT: WHAT AMERICA OWES TO BLACKS (2000).

247. See Albert O. HIRSChMAN, EXIT, VOICE, AND LOYALTY: RESPONSES to DECLINE IN FIRMS, ORGANIZATIONS, AND STATES 4-5 (1970). Hirschman suggests that where dissatisfied persons in the polity might register their dissatisfaction through "voice," those in the corporation are more likely to register their unhappiness through "exit." Id.; see also Samuel Issacharoff \& Richard H. Pildes, Politics as Markets: Partisan Lockups of the Democratic Process, 50 STAN. L. REV. 643, 649 (1998) ("If all else fails in the corporate sphere, the option of 'exit' is always available to the dissatisfied public shareholder. No such exit strategy exists in the political arena.").

248. On liberalism's overreliance on the availability of exit for members of a community, see Madhavi Sunder, Cultural Dissent, 54 STAN. L. REV. 495, 535-44 (2001).

249. Cf. Chander, Diaspora Bonds, supra note 5, at 1017. 
because of the inability of some to protect themselves by refusing to enter unattractive situations.

Finally, the amorphousness of racism has often been used to rebuff efforts to protect minority races. ${ }^{250}$ But corporate law demonstrates that amorphousness is not limited only to racism and its consequences. Despite the imprecision of standards ${ }^{251}$ such as "fairness," 252 "control," and "domination," 253 corporate law insists upon inquiry into these issues in order to reach an equitable result for minority shareholders. Judges must detect the presence of control, despite its "chameleon-like" 254 nature. The difficulty of the endeavor should not excuse us from its undertaking. Through experience with cases and precedents, judges routinely infuse content into amorphous standards.

Am I drawing the exactly wrong lesson from the markets? Should we not see the marketplace as the epitome of deracination-with differences found only in price and quality-rather than the identity of market participants? Consider Voltaire's heroic description of one marketplace:

Go into the Exchange in London, that place more venerable than many a court, and you will see representatives of all the nations assembled there for the profit of mankind. There the Jew, Mahometan, and the Christian deal with one another as if they were of the same religion, and reserve the name of infidel for those who go bankrupt. ${ }^{255}$

Voltaire's vision of a society of fellows united by a common enterprise despite private differences is certainly attractive. However, I believe it is inapposite for a number of reasons. First, markets themselves are not free of

250. See, e.g., Wygant v. Jackson Bd. of Educ., 476 U.S. 267, 276 (1986) (plurality opinion) ("No one doubts that there has been serious racial discrimination in this country. But as the basis for imposing discriminatory legal remedies that work against innocent people, societal discrimination is insufficient and over-expansive."); $c f$. Richard Delgado, Rodrigo's Second Chronicle: The Economics and Politics of Race, 91 MICH. L. REV. I183, 1189 (1993) (book review) (suggesting that "talk about a culture of racism, interest-convergence, hegemony, false consciousness" might be considered "vague and unquantifiable").

251. Corporate law often favors flexible, context-sensitive standards over rigid, bright-line rules. Duncan Kennedy has famously argued that the choice of standards in private law reflects an altruistic turn. Kennedy, supra note 194, at 1776. Kathleen Sullivan observes that while rules are associated with formal equality, standards often support substantive justice. Kathleen M. Sullivan, The Supreme Court, 1991 Term-Foreword: The Justices of Rules and Standards, 106 HARV. L. REV. 22, 62, 66 (1992).

252. See supra notes $223-237$ and accompanying text.

253. For a prominent recent example, see In re Walt Disney Co. Derivative Litig., 731 A.2d 342, 356-61 (Del. Ch. 1998), aff'd in part, rev'd in part sub nom. Brehm v. Eisner, 746 A.2d 244 (Del. 2000), where the Chancery Court "meticulously" inquired into whether Disney's Chairman and CEO, Michael D. Eisner, dominated the members of the Disney board. 746 A.2d at 258.

254. David C. Bayne, A Philosophy of Corporate Control, 112 U. PA. L. REV. 22, 30 (1963).

255. VOlTAIRE, On the Presbyterians, in PhilosophiCAL LeTTERs 25, 26 (Ernest Dilworth trans., 1961) (1732). 
the notice of the race, ethnic, or religious identity of the participants. ${ }^{256}$ Second and more importantly, even if markets were able to slough off ethnic identity, robust markets rely on a legal infrastructure that recognizes differential power relations among participants. ${ }^{257}$

\section{Which Minorities?}

Why compare minority shareholders to minority races? Why not compare minority shareholders to other kinds of minorities-minorities of very tall people, minorities of the very rich, or minorities of people who like broccoli? After all, any one of us is, by some measure, a member of a minority group. Should not we each deserve, by my reasoning, special protection?

The answer can be found in corporate law itself. Consider how minority shareholders are defined in corporate law: A Texan is not a "minority shareholder" simply because all the other shareholders are from New York. Rather, minority status among shareholders centers on share ownership and other indicia of control; it ignores other features that might be said logically to describe someone who is in a minority. Instead, corporate law reflects a concern for those who have small shareholdings, in the face of either large shareholders or the board of directors and corporate officers. While it is theoretically possible that New Yorkers in a corporation might gang up on Texans or that right-handers might gang up on lefties, there is little reason to suspect this to be the case and little history of actual oppression on such grounds.

Corporate law chooses which kinds of minorities to protect through experience and logic. And it chooses the label "minority" based on shareholding and power relations within the corporation. Corporate law thus offers a refinement to the traditional understanding of John Hart Ely's famous liberal defense of affirmative action. For Ely, affirmative action for African Americans lies beyond suspicion when enacted by a majority white legislature. He writes, "There is ... nothing constitutionally suspicious

256. AMY CHUA, WORLD ON FIRE: HOW EXPORTING FREE MARKET DEMOCRACY BREEDS ETHNIC HATRED AND GLOBAL INSTABILITY (2002); Lisa Bernstein, Opting Out of the Legal System: Extralegal Contractual Relations in the Diamond Industry, 21 J. LEGAL STUD. 115, 13841 (1992) (describing private law system among historically ethnically homogenous diamond merchants); Lan Cao, Looking at Communities and Markets, 74 NOTRE DAME L. REV. 841, 87492 (1999) (describing the operations of savings and credit associations formed by immigrant groups); Chander, Diaspora Bonds, supra note 5, at 1065-68 (describing Indian diaspora's purchase of Indian government's Resurgent India Bonds); Amy L. Chua, Markets, Democracy, and Ethnicity: Toward a New Paradigm for Law and Development, 108 YALE L.J. 1, 29-33 (1998) (identifying "market-dominant" ethnic minorities).

257. Comparative corporate governance theorists have demonstrated that minority protection is a key element in healthy capital markets. See supra notes 17-20 and accompanying text. 
about a majority's discriminating against itself....,258 Ely's focus on process follows footnote four of the Carolene Products decision, in which the Court expressed its concern with "prejudice against discrete and insular minorities"259 who are systematically disadvantaged in the political process. Ely's process-based jurisprudence offers a leading liberal justification for affirmative action. It identifies the groups warranting state protection on the basis of the political process. As Bruce Ackerman has shown, however, a focus on process alone (without reference to substantive conditions in society) is inadequate to the task of combating prejudice. ${ }^{260}$ Witness Justice O'Connor's use of Ely's argument in rejecting an affirmative action program instituted by a majority African-American city council. ${ }^{261}$

Corporate law would not make such a cursory assessment. For corporate law, mechanical judgments (such as simple nosecounting) tell only part of the story. Corporate law does not define "minority" shareholders on the basis of numbers alone. Rather it undertakes a contextual inquiry into relations of power within the corporation. Even minority holders can exercise control of the corporation. A sample of the results of judicial inquiries reads: "It is undisputed that the $44.4 \%$ acquired by Flintkote represented effective control of Gable. ${ }^{, 262}$ In Berger v. Berger, a court held that even a person who held ninety-eight percent of his company's stock could be a minority shareholder based on a "qualitative," not "mechanistic," assessment. ${ }^{263}$ Consider also a famous historical episode: John D. Rockefeller "succeeded in his famous struggle to oust the chairman of the board of Standard Oil of Indiana despite controlling only $14.9 \%$ of Standard Oil's stock.",264 New York's "constituency statute" recognizes that control may be exercised even without majority ownership of voting stock; the statute defines "control" as "the possession, directly or indirectly, of the power to direct or cause the direction of the management and policies of the corporation, whether through the ownership of voting stock, by contract, or otherwise." ${ }^{265}$ Control groups in corporations quite commonly-perhaps even usually-own less than a majority of the stock. ${ }^{266}$ Owners of a plurality of the shares often exert power similar to

258. ELY, supra note 185, at 172; see also John Hart Ely, The Constitutionality of Reverse Racial Discrimination, 41 U. CHI. L. REV. 723 (1974).

259. United States v. Carolene Prods. Co., 304 U.S. 144, 152 n.4 (1938).

260. Bruce A. Ackerman, Beyond Carolene Products, 98 HARV. L. REV. 713, 739-40 (1985).

261. City of Richmond v. J.A. Croson Co., 488 U.S. 469, 495-96 (1989) (plurality opinion) (citing Ely for two propositions-that a white majority disadvantaging itself is not constitutionally suspect, and that a black majority disadvantaging whites is not suspect).

262. Zetlin v. Hanson Holdings, Inc., 397 N.E.2d 387, 388 (N.Y. 1979) (mem.).

263. 592 A.2d 321, 326-28 (N.J. Super. Ct. Ch. Div. 1991).

264. BERLE \& MEANS, THE MODERN CORPORATION 1932, supra note 41, at 4.

265. N.Y. BUS. CORP. LAW $§ 717$ (McKinney 2003).

266. But see Coffee, supra note 56, at 397 (arguing that the prospect of control by a small minority has become "increasingly remote" as a result of the rise of institutional investors). 
that of a true majority. ${ }^{267}$ Indeed, the American Law Institute even presumes control on the basis of more than twenty-five percent ownership (though the judiciary has thus far resisted reliance on quantitative rules alone). ${ }^{268}$

The irony is that, despite Justice O'Connor's citation of Ely to the contrary, Ely himself understands this. Indeed, he submitted a brief in Croson (on behalf of the American Civil Liberties Union) arguing exactly this point:

The fact that racial minorities may constitute $50 \%$ of the general population in some cities, as they do in Richmond, does not automatically render whites a "discrete and insular minority" invoking suspect classification analysis. Mere numerical majority does not translate automatically into political domination. The political strength of an identifiable group depends, inter alia, on voting registration rates, political cohesiveness and organization, and, of course, economic resources. ${ }^{269}$

Ely would have us look at the substantive conditions in society that make certain groups more or less vulnerable to abuse through the political process.

The constant need to assess power dynamics reflects the contingent nature of law itself. While prominent scholars detect the end of history for corporate law, ${ }^{270}$ the focus on experience that I suggest here requires a more dynamic, even humble, attitude. As conditions change, we may find that the minorities needing protection may change as well. As the structure of ownership shifts from state-sanctioned monopolies to state socialism, to family corporations, to dispersed shareholders, to oligarchs, to trusts, or to pension funds, law must ready itself for each turn. The American Law

267. See 2 James D. Cox \& Thomas leE Hazen, CoX \& HAZEN on CoRporations $\S 14.03$, at $824-25$ ( $2 \mathrm{~d}$ ed. 2003 ) (listing myriad ways that a minority shareholder may assert control, including agreements, veto power, and the setting of dividend schedules); Loftus C. Carson, II, The Liability of Controlling Persons Under the Federal Securities Acts, 72 NOTRE DAME L. REV. 263, 286 (1997) ("Shareholdings may provide a source of power that enables their holder to exercise actual control, even when such holdings are less than the majority...."). Typically, the ability of less-than-majority holders to exercise working control rests largely on the diffusion of the remaining shareholders. See BERLE \& MEANS, THE MODERN CORPORATION 1932, supra note 41 , at 4 ("Frequently ... ownership is so widely scattered that working control can be maintained with but a minority interest.").

268. 1 PRINCIPLES OF CORPORATE GOVERNANCE, supra note $34, \S 1.10(\mathrm{~b})$ ), at 14 ("A person who, either alone or pursuant to an arrangement or understanding with one or more other persons, owns or has the power to vote more than 25 percent of the outstanding equity securities of a corporation is presumed to exercise a controlling influence over the management or policies of the corporation ....")

269. Brief of Amicus Curiae American Civil Liberties Union at 12 n.7, City of Richmond v. J.A. Croson Co., 488 U.S. 469 (1998) (No. 87-998), available at 1987 U.S. Briefs 998 (LEXIS).

270. E.g., Henry Hansmann \& Reinier Kraakman, The End of History for Corporate Law, 89 GEO. L.J. 439 (2001). 
Institute recognized this nearly a century ago: "There will never be a time when the work is done and its results labeled 'A Complete Restatement of the Law." "271 The law is a work in progress; it is in permanent reform. Our work is to keep time's arrow pointing in the direction of greater human capability. ${ }^{272}$

Similarly, if and when that magical moment arrives when societal and economic conditions no longer warrant affirmative action for today's racial minorities, law must adapt. The Supreme Court's recent enunciation of its expectation that " 25 years from now, the use of racial preferences will no longer be necessary" ${ }^{273}$ to foster student body diversity seems optimistic but not entirely misdirected. While it seems unlikely that racial parity will be achieved at any time in the near future, we must always be willing to reconsider our efforts, especially with respect to the enumeration of the protected classes. As power relations in society turn upside down (or in any other direction), the beneficiaries of any affirmative action must change accordingly. ${ }^{274}$

\section{INCORPORATION}

What exactly then can constitutional law learn from corporate law?

To appropriate wholesale corporate law's mechanisms for minority protection seems unwise, mistaking metaphor for identity. Many corporate protections are peculiar to that environment. Yet, there will also be mechanisms that might prove relevant. Consider Lani Guinier's famous borrowing from corporate law in her proposal for cumulative voting in political elections. ${ }^{275}$ Guinier's proposal simply retraced the path taken by corporate law, now from the other direction; as we have seen, cumulative voting in corporate law itself had roots in John Stuart Mill's classical political liberalism. ${ }^{276}$

271. 2 PRINCIPLES OF CORPORATE GOVERNANCE, supra note 34, at xxii (quoting 1923 Report of the Committee on the Establishment of a Permanent Organization for the Improvement of the Law); see also $1 \mathrm{id}$. at 200 (observing that "the duty of fair dealing" is not a "final, complete, and unchanging concept, but rather ... a concept that will continue to evolve as new problems and circumstances stimulate and challenge our system of corporate governance").

272. On capabilities, see AmARTYA SEN, Development as FreEDom 3 (2000); and Amartya Sen, Rights and Capabilities, in MORALITY AND OBJECTIVITY: A TRIBUTE TO J.L. MACKIE (Ted Honderich ed., 1985).

273. Grutter v. Bollinger, 123 S. Ct. 2325, 2347 (2003).

274. For example, Margaret Jane Radin, speaking of the double bind of commodification-its threat to personhood coupled with the possible economic advantage for the person who is the object of commodification-suggests that we must choose whether or not to permit commodification based on existing societal circumstances, but "we must keep re-deciding as time goes on." Margaret Jane Radin, The Pragmatist and the Feminist, 63 S. CAL. L. REV. 1699, 1700 (1990).

275. E.g., Guinier, No Two Seats, supra note 11, at 1437-43; Guinier, The Triumph of Tokenism, supra note 11, at 1136-53.

276. See supra notes 154-160 and accompanying text. 
But corporate law's principal instruction may come not in technology, but in philosophy. Corporate law teaches us how we might approach the project of minority protection generally. In this final Part, I apply corporate lessons about minority protection to the project of racial equality. I consider three contemporary civil rights debates - each a contemporary flashpoint - centering on the issue of affirmative action.

\section{A. Grutter and Gratz}

Consider first the highly charged issue before the Supreme Court in its last Term: the validity of race-based affirmative action programs in higher education. The cases of Grutter v. Bollinger ${ }^{277}$ and Gratz v. Bollinger ${ }^{278}$ tested the constitutionality of racial preferences in law school and undergraduate admissions, respectively, at the prestigious University of Michigan at Ann Arbor. White applicants denied admission challenged (1) the law school's policy of, inter alia, seeking to maintain a "critical mass" of "students from groups which have been historically discriminated against, like African-Americans, Hispanics and Native Americans,"279 and (2) the college's policy of awarding a significant number of "plus points" in the admissions process to members of these same groups. The plaintiffs argued that the University's admissions programs violated the constitutional guarantee of equal protection, which they understood to require identical treatment of all applicants. ${ }^{280}$ The University of Michigan replied that an adverse ruling would precipitate "the immediate resegregation" of this country's finest educational institutions. ${ }^{281}$

Grutter, Gratz, and the other plaintiffs saw in the cases the opportunity to further the journey upon which the Supreme Court had seemed to embark - toward the utopia of governmental colorblindness. In its recent decisions prior to Grutter and Gratz, the Court had moved definitively, if not steadily, ${ }^{282}$ toward a colorblind model. It has traveled from Wygant $v$. Jackson Board of Education, which demanded a " "most searching examination" of any racial preference, ${ }^{283}$ to City of Richmond v. J.A. Croson Co., which rejected evidence of past societal discrimination as too

277. 123 S. Ct. 2325.

278. 123 S. Ct. 2411 (2003).

279. Grutter, $123 \mathrm{~S}$. Ct. at 2332 (internal quotation marks omitted).

280. Petition for Writ of Certiorari at 26, Grutter (No. 02-241) (arguing that the issue is "whether our Nation's principles of equal protection and non-discrimination mean the same thing for all races").

281. Brief in Opposition to Petition for Writ of Certiorari at 21, Grutter (No. 02-241).

282. See Metro Broad., Inc. v. FCC, 497 U.S. 547 (1990), overruled in part by Adarand Constructors, Inc. v. Pena, 515 U.S. 200 (1995).

283. 476 U.S. 267, 273-74 (1986) (plurality opinion) (quoting Fullilove v. Klutznick, 448 U.S. 448, $491(1980))$. 
general to establish a compelling state interest in a racial preference, ${ }^{284}$ to Adarand Constructors, Inc. v. Pena, which required the same level of scrutiny for a preference, regardless of "'the race of those burdened or benefited" 285 or the "good intentions",286 of its proponents.

The ideology of governmental colorblindness does not deny the persistence of difference within the polity. Rather it proposes that law must ignore such difference, lest it become complicit in its perpetuation. But consider an early formulation of the colorblind principle, articulated by the elder Justice Harlan, dissenting, in Plessy v. Ferguson:

The white race deems itself to be the dominant race in this country. And so it is, in prestige, in achievements, in education, in wealth and in power. So, I doubt not, it will continue to be for all time, if it remains true to its great heritage and holds fast to the principles of constitutional liberty. But in view of the Constitution, in the eye of the law, there is in this country no superior, dominant, ruling class of citizens. There is no caste here. Our Constitution is colorblind .... ${ }^{287}$

Justice Harlan's entreaty to the "white race" reveals the studied ignorance that law must affect if it adopts the mandate of colorblindness. Despite the white race's apparent superior position-a position that Justice Harlan hoped would be perpetual-law should not notice racial difference.

In Grutter and Gratz, the Court did not adopt the principle of governmental colorblindness. Indeed, Grutter specifically reaffirmed the ability of the state to consider the race of students in higher education admissions, even to establish a "critical mass" of minority students. Yet, despite affirming race consciousness, the Court resisted recognizing the principal basis for race consciousness: the fact that power and race are closely intertwined in contemporary society. The Court only fleetingly acknowledged "our Nation's struggle with racial inequality." 288 In a sense

284. 488 U.S. 469,500 (1989) (plurality opinion).

285. 515 U.S. at 222 (quoting Croson, 488 U.S. at $493-94$ (plurality opinion)).

286. Id. at 228 .

287. 163 U.S. 537, 559 (1896) (Harlan, J., dissenting): Justice Harlan's statement that "[t]here is no caste here" seems to assume that caste must be legally sanctioned. But if society severely circumscribes occupational opportunities based on one's parents' socioeconomic status, a kind of caste system emerges, whether or not it is sanctioned by law. Additionally, despite Justice Harlan's insistence on colorblindness, he observes without criticism the law's exclusion of members of the Chinese race: "There is a race so different from our own that we do not permit those belonging to it to become citizens of the United States. Persons belonging to it are, with few exceptions, absolutely excluded from our country. I allude to the Chinese race." Id. at 561 (Harlan, J., dissenting).

288. Grutter v. Bollinger, 123 S. Ct. 2325, 2344 (2003); see also id. at 2341 (observing that our society is one "in which race unfortunately still matters"). 
then, the Court followed Justice Harlan's mandate to avoid notice of existing conditions of superiority and inferiority.

Rather than focusing on societal conditions that necessitate affirmative action, the Court embraced the goal of fostering student body diversity ${ }^{289}$ Diversity is a powerful idea, a means to strengthen not just investment portfolios, but also institutions. Diversity holds promise as a basis for supporting affirmative action programs, not just in education, but also in employment and in distributing governmental largesse. Justice Scalia recognized as much in his dissent in Grutter, suggesting that,

[i]f it is appropriate for the University of Michigan Law School to use racial discrimination for the purpose of putting together a "critical mass" that will convey generic lessons in socialization and good citizenship, surely it is no less appropriate-indeed, particularly appropriate-for the civil service system of the State of Michigan to do so. ${ }^{290}$

Indeed, the Supreme Court had already relied on diversity to justify a federal minority preference program in the transfer of broadcast licenses. ${ }^{291}$

Yet, the failure to recognize the operation of power leaves governmental action to protect racial minorities on a relatively weak footing. This failure limits the subtlety of governmental programs, which must now focus broadly on fostering a rainbow of views, rather than redressing directly conditions of inequality. It also offers a weaker sense of justice. Consider Justice Scalia's sarcastic description of the results of affirmative action: "The nonminority individuals who are deprived of a legal education, a civil service job, or any job at all by reason of their skin color will surely understand," ${ }^{, 92}$ he writes. Justice Scalia's concern seems reasonable: After all, how can one appreciate the need for affirmative action in any context without a strong consciousness of discrimination in

289. Id. at 2338 (upholding the law school's affirmative action program, which seeks to "obtain[] the educational benefits that flow from a diverse student body" (internal quotation marks omitted)).

290. Id. at 2349 (Scalia, J., concurring in part and dissenting in part). By this example, Justice Scalia hoped to show that the diversity rationale justifies too much governmental race consciousness.

291. Metro Broad., Inc. v. FCC, 497 U.S. 547, 600 (1990), overruled in part by Adarand Constructors, Inc. v. Pena, 515 U.S. 200 (1995). While the Court in Metro Broadcasting scrutinized that program less searchingly than demanded by the Court's later opinion in Adarand, 515 U.S. at $226-27$, it remains an open question whether the diversity rationale might offer a compelling governmental interest justifying the broadcast license program.

292. Grutter, $123 \mathrm{~S}$. Ct. at 2349 (Scalia, J., concurring in part and dissenting in part). Justice Scalia's reference to the "nonminority individual" is incorrect: He meant to refer to individuals who do not benefit directly from affirmative action; affirmative action programs often exclude some racial minority groups-principally Asians-from their benefits. 
society? $?^{293}$ Not only might certain individuals feel wronged, but, more fundamentally, the judiciary might fail to recognize the role of law in constructing equality.

Corporate law, as we have seen, seeks a much richer informational base upon which to form its judgments. Rather than studied ignorance, it explicitly examines who is in control and who is a minority susceptible of exploitation. It meticulously examines power, and learns from experience with power's operation. Its structure is elaborately designed to protect minority shareholders against the wrongdoing of controlling shareholders or management. Where the Supreme Court has at times demanded an exacting demonstration of individualized history of disadvantage before permitting special protection, ${ }^{294}$ corporate law eschews any demand for such a historical record before imposing its specialized obligations. It assumes that minorities are at risk of unfair treatment, and acts accordingly.

Furthermore, while critics decry what they see as the stigmatizing effect of affirmative action and the racial "paternalism"295 it reveals, no such stigma attaches to minority shareholders, despite corporate law's substantial protections. The need for minority shareholder protection does not impugn the capacity or honor of minority shareholders. The minority shareholder is not described as incompetent because she could not negotiate sufficient protections for herself. Rather, such protections are understood as necessary given the power relations within the firm. Perhaps one can sensibly understand affirmative action as a similar response. Given societal circumstances, affirmative action might be due to individuals whose lack of power makes them more vulnerable to the unequal distribution of educational and economic opportunities. Instead of stigmatizing certain racial minorities as less worthy recipients of governmental largesse, we might better understand affirmative action as akin more to fiduciary duties and securities regulation - as yet another device to protect those vulnerable to exploitation.

Most importantly, if the elaborate edifice of minority shareholder protection is justified by concerns for fairness or capital formation, it seems appropriate to ask if such concerns might not also justify protections for minority races. Corporate law, as we have seen, promotes capital formation and fairness by taking into account power relations within an institution. ${ }^{296}$

293. Justice Ginsburg's forthright recognition that "[i]n the wake 'of a system of racial caste only recently ended,' large disparities endure" stands in sharp contrast to the tenor of the Court's own opinion. Gratz v. Bollinger, 123 S. Ct. 2411,2443 (2003) (Ginsburg, J., dissenting) (quoting Adarand, 515 U.S. at 273 (Ginsburg, J., dissenting) (citation omitted)).

294. See City of Richmond v. J.A. Croson Co., 488 U.S. 469, 498-508 (1989) (plurality opinion).

295. E.g., Adarand, 515 U.S. at 240 (Thomas, J., concurring in part and concurring in the judgment).

296. See supra Section II.A. 
I argue that these same two fundamental goals should also be well served by legal protections for minority races.

Racial minorities in the United States face discrimination from cradle to grave. A principal result of antidiscrimination laws is that discrimination is now hidden, operating in ways that are difficult to specify. Based on empirical studies, Ian Ayres concludes that in a variety of markets-from car sales to kidney transplants-blacks and women are consistently at a disadvantage. ${ }^{297}$ The Supreme Court has recognized the persistence of racial discrimination, even while denying a basis for affirmative action. As Justice O'Connor acknowledged for the Court in Adarand, "The unhappy persistence of both the practice and the lingering effects of racial discrimination against minority groups in this country is an unfortunate reality ....,298

Economic analysis finds such discrimination inefficient. Gary Becker's seminal work on the economics of employment discrimination suggests that competitive markets would, on their own, eliminate discrimination because of its inefficiency. ${ }^{299}$ The discriminating producer, Becker argues, would be driven from the market. Kenneth Arrow observes the irony in Becker's theory, which "predicts the absence of the phenomenon it was designed to explain." ${ }^{300}$ Arrow himself suggests an alternative explanation: Because the productivity of prospective workers is not directly observable, employers might rely on proxies for productivity. ${ }^{301}$ If race serves as such a proxy, and if whites on average are more productive than minorities because of educational or other advantages, then employers might hire based on racein spite of the high (but unobservable) qualifications of any individual minority person. Statistical discrimination is especially pernicious because it is self-fulfilling: "If the employer is going to judge by race, then there is

297. IAN Ayres, PERVASIVE PREJUdice?: UNCONVENTIONAL EVIDENCE OF RACE AND GENDER DISCRIMINATION 19, 165 (2001).

298. Adarand, 515 U.S. at 237. Adarand's concession that discrimination persists now contrasts with the Court's earlier statement in Wygant v. Jackson Board of Education, which conceded only that discrimination has existed in the past, without admitting its continuing role in society. Wygant v. Jackson Bd. of Educ., 476 U.S. 267, 276 (1986) (plurality opinion) ("No one doubts that there has been serious racial discrimination in this country."); see also Croson, 488 U.S. at 499 (plurality opinion) (noting the "somy history of both private and public discrimination").

299. GARY S. BECKER, THE ECONOMICS OF DISCRIMINATION (1957).

300. Kenneth J. Arrow, Some Mathematical Models of Race Discrimination in the Labor Market, in RACIAL DISCRIMINATION IN ECONOMIC LIFE 187, 192 (Anthony H. Pascal ed., 1972).

301. But after some three decades of study, Arrow has now concluded that discrimination may persist, despite its inefficiencies, because of nonmarket factors. See Kenneth J. Arrow, What Has Economics To Say About Racial Discrimination?, J. ECON. PERSP., Spring 1998, at 91, 93. Noneconomic motivations for discrimination might include a desire for group status production, with individuals making material sacrifices (in the form of inefficient production) for group welfare. See Richard H. McAdams, Cooperation and Conflict: The Economics of Group Status Production and Race Discrimination, 108 HARV. L. REV. 1003, 1009-19 (1995). 
no reward for... [human capital] investments." ${ }^{, 302}$ With minorities no longer investing in education, the statistical discriminator will over time have her discriminatory instinct confirmed.

The major economic theories of discrimination all share a central belief-racial discrimination in employment harms economic production. They differ only on its etiology and on the appropriate remedy. While a few scholars such as Richard Epstein and Richard Posner argue that state intervention to eliminate discrimination is unwise, ${ }^{303}$ others maintain that legal intervention can help ameliorate the distorting effects of discrimination. John Donohue has argued that legal intervention to eliminate discrimination increases efficiency faster than the self-correcting processes of the market. ${ }^{304}$ Affirmative action to promote minority employment should help counter the pernicious effects of racism on productivity, producing a larger, more capable work force. In general, affirmative action in employment should help the goal of capital formation. $^{305}$

The same is true of education. The economic analysis of investments in human capital supports the need for affirmative action in education. Becker's work in "human capital" demonstrates the important role that education plays in productivity as reflected in income. ${ }^{306}$ Orley Ashenfelter and Cecilia Rouse establish that better-educated people have higher incomes, even taking into account differences in so-called innate ability. ${ }^{307}$ An economy that has more well-trained workers would seem to be better positioned for growth. Affirmative action both in education and employment might help end the "poverty trap"308 into which many minority families appear to fall, allowing them to become more economically productive members of society.

302. Arrow, supra note 301, at 96-97; see also John J. Donohue III, Further Thoughts on Employment Discrimination Legislation: A Reply to Judge Posner, 136 U. PA. L. REV. 523, 532-33 (1987).

303. Richard A. EPSTEIN, ForbidDEN GRounds: THE CASE AGAINST EMPloyment DisCRIMINATION LAWS (1992); Richard A. Posner, The Efficiency and the Efficacy of Title VII, 136 U. PA. L. REV. 513 (1987). Their argument would oddly permit private discrimination against minorities, but prohibit public action on minorities' behalf.

304. Donohue, supra note 302, at 532-33 (citing John J. Donohue III, Is Title VII Efficient?, 134 U. PA. L. REV. 1411 (1986)).

305. I do not mean to hold affirmative action hostage to the ruthless machine of efficiency, but rather to show that our interests in the two are likely to coincide. That said, if an affirmative action program proves inefficient, we should revise it to improve its utility-generating effects.

306. GARY S. BECKER, HUMAN CAPITAL 17 (3d ed. 1993) (concluding that "high school and college education in the United States greatly raise a person's income").

307. Orley Ashenfelter \& Cecilia Rouse, Schooling, Intelligence, and Income in America, in MERITOCRACY AND ECONOMIC INEQUALITY, supra note 5, at 89.

308. Shelly J. Lundberg \& Richard Startz, Inequality and Race: Models and Policy, in MERITOCRACY AND ECONOMIC INEQUALITY, supra note 5, at 269, 280 (describing "poverty traps" in which groups may be perpetually caught through accidents of history). 
Indeed, a number of the nation's Fortune 500 companies, including many household names, declared to the Supreme Court their strong interest in continuing affirmative action in higher education. In a brief in support of the University of Michigan in Grutter and Gratz, these companies argued that a workforce, both educated within an ethnically diverse environment and itself ethnically diverse, offers substantial advantages in an ethnically diverse national and global economy. ${ }^{309}$ These companies also emphasized the breadth of the population they serve, noting, for example, that " $[a]$ micus Procter and Gamble sold a branded product to more than 2.5 billion people across the world last year." ${ }^{, 10}$ Surely it is useful to employ a diverse workforce to sell to such a diverse population. But while the brief was correct in identifying affirmative action as useful in hiring a racially diverse workforce, it left undisturbed the underlying notion of white superiority. The brief implies that nonwhites might be good employees because they can help sell products to other nonwhites. It never squarely says what the economic theory we have reviewed above suggests-that bringing additional groups into the workforce for highly skilled labor will improve the quality of the workforce overall. Not only will minorities add to the ability to sell to other nonwhite consumers, but they will also improve the quality of the product, the design of the factory, the beauty of the promotional materials, and the strategy for sales. Affirmative action at the University of Michigan and other educational institutions draws groups into the workforce for corporate America, increasing the talent pool from which it can draw. Corporate law, too, we have seen, ensures minority protection in part because of its desire to obtain minority participation in the capitalist enterprise, thereby improving the enterprise through the additional capital contributed by the minority.

This argument about capital formation and fairness has avoided the language of constitutional law in favor of consequentialist, policy-oriented arguments. But, of course, the constitutional jurisprudence of affirmative action itself turns on these types of arguments-from concerns about a debilitating "stigma" to broader notions of societal progress. ${ }^{311}$ The policy arguments I have suggested here respond directly to those of affirmative action's opponents. Stigmatization is revealed as inappropriate when governmental intervention responds to the abuse of power, and societal progress seems more likely through broader availability of the most prestigious institutions of higher education. But we can go farther yet. We

309. Brief for Amici Curiae 65 Leading American Businesses in Support of Respondents, Grutter v. Bollinger, 123 S. Ct. 2325 (2003) (No. 02-241). The companies include many of America's household names, including both Coca-Cola and Pepsi, as well as Alcoa, American Airlines, General Electric, Kellogg, Kraft, Merck, Microsoft, Procter \& Gamble, Reebok, Sara Lee, Shell Oil, United Airlines, Whirlpool, and Xerox.

310. Id. at 7 .

311. See Jed Rubenfeld, Affirmative Action, 107 YALE L.J. 427, 446-48 (1997). 
have seen that judges considering corporate cases review structural reasons for unfairness-from dispersed shareholding to in-group biases among independent directors-instead of requiring purely individualized showings of disadvantage and oppression. Such structural concerns would plainly prove helpful in the constitutional context as well.

As I have shown, a general concern with capital formation and fairness might often lead us to adopt affirmative action programs in employment and education, just as we do in corporate law on behalf of minority shareholders. $^{312}$ If structural subordination is the problem, it must be addressed directly by laws that acknowledge it. In such conditions, Lady Justice must take off her blindfold. ${ }^{313}$

\section{B. The Racial Blindness Initiative}

Consider a new constitutional initiative from my home state of California-being put to the electorate as this Essay goes to press-which promises to be as divisive as Proposition 209. ${ }^{314}$ The new initiative, which I call the "Racial Blindness Initiative,", 315 would prevent the government from collecting information about race, thus carrying the banner of colorblindness to its logical conclusion.

This initiative would force racial indifference on state government by preventing it from gathering racial information-in employment, in education, and in law enforcement. ${ }^{316}$ Of course, government workers could secretly still make personal assessments of race-based on appearance, speech, domicile, and name. Rather, the measure would find its significance in denying the government any systematic ability to engage in affirmative action. At the same time, it would deny minorities the factual record that would facilitate claims for police harassment and governmental redlining. It

312. See supra Section II.A.

313. Despite the Court's failure to acknowledge forthrightly the role of power, the Court's opinion in Grutter does offer the seeds of a more robust jurisprudence. Writing for the Court, Justice O'Connor acknowledged the role of universities as the "training ground for . . our Nation's leaders" and the need for "all members of our heterogeneous society [to] participate in the educational institutions that provide the training and education necessary to succeed in America." Grutter, $123 \mathrm{~S}$. Ct. at 2341. This recognition offers a foundation not just for diversifying student bodies, but also for a more active program of promoting minorities.

314. Proposition 209 amended the California Constitution to ban preferential treatment in public hiring, contracting, and school admissions. CAL. CONST. art. I, $\S 31$ ("The state shall not discriminate against, or grant preferential treatment to, any individual or group on the basis of race, sex, color, ethnicity, or national origin in the operation of public employment, public education, or public contracting.").

315. Proposition 54, Classification by Race, Ethnicity, Color, or National Origin (certified Cal. 2003) (to be enacted as CAL. CONST. art. I, §32), at http://voterguide.ss.ca.gov/ propositions/2-3-prop-54.html [hereinafter Racial Blindness Initiative].

316. The government would also not be able to collect racial information with respect to any other functions, except where the legislature approved an exception by two-thirds of each house and the Governor signed it. Id. §32(b) (to be enacted as CAL. CONST. art. I, § 32(b)). 
would no longer be possible to determine if government actions carried discriminatory impacts. The measure would also likely moot Supreme Court rulings on the constitutionality of affirmative action, at least with respect to actions by the State of California. ${ }^{317}$ Furthermore, like Proposition 209 before it, the Initiative aspires to be a model for similar grassroots action throughout the United States.

We might reflect on this initiative by imagining a similar initiative in the corporate context. Call this hypothetical proposal the "Shareholder Blindness Initiative." This measure would deny the law access to information about the stake that any particular shareholder had in the corporation. Rather than viewing each shareholder differently according to control or minority status, all shareholders would be treated the same. Bill Gates, Warren Buffett, and the small pensioner are all rendered equal-by law, if not in fact.

In our real world, however, corporate law does not adopt an approach of formal equality, refusing to recognize differences among shareholders. Corporate law does not confuse equality with sameness. Indeed, corporate law even goes so far as to impose special duties on controlling shareholders and managers that are not borne by minority shareholders. Corporate law recognizes what this initiative would deny: In order to do justice, law must keep in mind the identity of the individuals involved-specifically, whether they are controlling or minority members of the relevant group.

Of course, states have long employed racial classification as a tool for subjugation. In fact, such state efforts helped produce our modern understandings of race. ${ }^{318}$ The apparatus of identification is a necessary precondition to the operation of domination. Benedict Anderson writes of the use of census categories by the colonial state in Southeast Asia: "Guided by its imagined map [the colonial state] organized the new educational, juridical, public-health, police, and immigration bureaucracies it was building on the principle of ethno-racial hierarchies . ..." ${ }^{319}$ Even the Racial Blindness Initiative would preserve the ability of the state to engage

317. Cf. Smith v. Univ. of Wash. Law Sch., 233 F.3d 1188, 1193-95 (9th Cir. 2000) (observing that a suit challenging an affirmative action program at a state law school would be moot because a Washington State constitutional initiative-modeled on California's Proposition 209-had already prohibited any racial preference in education).

318. See IAN HANEY LOPEZ, WHITE BY LAW (1996); see also Bill Ong Hing, Beyond the Rhetoric of Assimilation and Cultural Pluralism, 81 CAL. L. REV. 863, 879-85 (1993) (addressing the tension of separatism and conflict in an immigration-driven and multicultural society); Kevin R. Johnson, Race and Immigration Law and Enforcement, 14 GEO. IMMIGR. L.J. 289, 292-96 (2000) (responding to the question of whether there is a plenary power doctrine); Spencer Overton, Voices from the Past: Race, Privilege, and Campaign Finance, 79 N.C. L. REV. 1541 , 1544-52 (2001) (analyzing the role of race and privilege in campaign finance).

319. BENEDICT ANDERSON, IMAGINED COMMUNITIES: REFLECTIONS ON THE ORIGIN AND SPREAD OF NATIONALISM 169 (1991). 
in racial identification for "law enforcement" purposes. ${ }^{320}$ But a tragic history of employing race as a device for targeted oppression should not lead us now to reject state knowledge of race when employed to achieve justice. Given the coincidence of the distribution of power with racial identity in our society, the state would handicap itself severely by refusing to recognize the race of its citizens in its efforts to achieve social justice.

\section{A Majority of Minorities}

Finally, consider the coming demographic shift-already reality in California $^{321}$ - where minority races make up a majority of the population. ${ }^{322}$ With this shift, we will see the emergence of the argument that, even if minorities once needed legal protection, they no longer deserve special protection because they now are in the majority. After all, why should the law worry about protecting the majority of the population from subjugation by the minority? ${ }^{323}$ Indeed, should not law protect whites from the majority of other races? In rejecting an affirmative action program in employment, Justice O'Connor noted that it was devised by a majority African-American city council. ${ }^{324}$

But juxtapose this recent statement from a state supreme court: "[N]otwithstanding its 43.3 percent minority ... interest, [one party] did exercise control over [another party] by dominating its . . . affairs.",325 This statement, of course, arose in a corporate setting; the specific reference is to a controlling shareholder-Alcatel-that violated its duties to the small investors in the corporation, even though it held but a minority of the shares. Corporate law understands that control does not require strict numerical advantage, though numbers certainly help. ${ }^{326}$ It makes more

320. Racial Blindness Initiative $\S 32(\mathrm{~g})$ (to be enacted as CAL. CONST. art. I, $\S 32(\mathrm{~g})$ ) ("Nothing in this section shall prevent law enforcement officers, while carrying out their law enforcement duties, from describing particular persons in otherwise lawful ways.").

321. CAL. DEP'T OF Fin., CALIFORNIA CURRENT POPULATION SURVEY REPORT: MARCH 2002 DATA 1 (2003) (reporting that non-Hispanic whites were $45.7 \%$ of California's population in March 2002), at www.dof.ca.gov/html/demograp/cps-2002.pdf.

322. The United States Census Bureau projects that non-Hispanic whites will fall out of the majority by the middle of this century. U.S. CENSUS BUREAU, PROJECTIONS OF THE RESIDENT POPULATION BY AGE, SEX, RACE, AND HISPANIC ORIGIN: 1999 TO 2100 (2000).

323. One possible answer might come from work in public choice, which recognizes the possibility that mobilized interest groups in a democracy might be able to capture political decisionmaking even in the absence of majority support.

324. See City of Richmond v. J.A. Croson Co., 488 U.S. 469, $495-96$ (1989) (plurality opinion).

325. Kahn v. Lynch Communication Sys., Inc., 638 A.2d 1110, 1115 (Del. 1994).

326. See, e.g., Citron v. Fairchild Camera \& Instrument Corp., 569 A.2d 53, 70 (Del. 1989) ("' [A] shareholder who owns less than $50 \%$ of a corporation's outstanding stocks does not, without more, become a controlling shareholder of that corporation, with a concomitant fiduciary status.' For a dominating relationship to exist in the absence of controlling stock ownership, a 
nuanced assessments of actual relations of power within the corporate hierarchy. ${ }^{327}$ Even those holding thirty-five percent of the shares might make ninety-five percent of the decisions. Indeed, corporate law usually prefers to speak in terms of minority and controlling shareholders, not minority and majority shareholders.

My point is well made by the Fifth Circuit, in a 2000 decision that explicitly considered minorities and majorities: "[T]he question of minority versus majority should not focus on mechanical mathematical calculations, but instead, 'The question is whether they have the power to work their will on others ....",328 Ironically, in Hopwood v. Texas, the same court had dramatically rejected the affirmative action program of the University of Texas School of Law. ${ }^{329}$

Reliance on numerical disadvantage alone to identify vulnerable groups will prove both over- and underinclusive. Such a simplistic rule would seek to protect men from women, as women outnumber men. ${ }^{330}$ This formalist procedural view mistakes number for power. ${ }^{331}$ Corporate law, on the other hand, does not find it at all surprising that majorities may not command power commensurate with their number. ${ }^{332}$ Corporate law recognizes that control may follow from other resources. Indeed, the feminist focus on

plaintiff must allege domination by a minority shareholder through actual control of corporate conduct." (quoting Gilbert v. El Paso Co., 490 A.2d 1050, 1055 (Del. Ch. 1984))).

327. See, e.g., Coffee, supra note 18, at 647 (describing methods whereby block holders of equity outside the United States often exercise control of a corporation without having majority ownership of that corporation); Deborah A. DeMott, The Mechanisms of Control, 13 CoNN. J. INT'L L. 233, 235-51 (1999) (illustrating many forms of control in relationships between corporations); Mary Siegel, The Erosion of the Law of Controlling Shareholders, 24 DEL. J. CORP. L. 27, 34 (1999) ("There is no set percentage of stock that will automatically place a minority shareholder under the fiduciary rubric. The key factor is the ability to dictate the terms of a transaction.").

328. Hollis v. Hill, 232 F.3d 460, 466 (5th Cir. 2000) (quoting Bonavita v. Corbo, 692 A.2d 119, 124 (N.J. Super. Ct. Ch. Div. 1996)).

329. Hopwood v. Texas, 78 F.3d 932, 934 (5th Cir.), vacated by 95 F.3d 53 (5th Cir.), cert. denied, 518 U.S. 1033 (1996).

330. In this example, a numerical rule would be simultaneously overinclusive because it would posit men as a class to be protected from women and underinclusive because it would deny women any heightened scrutiny of gender classifications.

331. Dissenting from the Supreme Court's decision to bar Virginia's all-male military academy, Justice Scalia offered this process-based explanation for why women should not deserve heightened judicial solicitude. United States v. Virginia, 518 U.S. 515, 575 (1996) (Scalia, J., dissenting) (declaring that women are not a "discrete and insular minorit[y]' unable to employ the 'political processes"' (quoting United States v. Carolene Prods. Co., 304 U.S. 144, 152 n.4 (1938) (alteration in original))). The Court's embrace of heightened scrutiny for gender discriminations, see Virginia, 518 U.S. at 532-33, suggests that the Court is not wholly blind to the vulnerability of women despite their majority status, though the Court's gender discrimination jurisprudence offers a formally equal concern for both men and women. See, e.g., J.E.B. v. Alabama ex rel. T.B., 511 U.S. 127 (1994).

332. BERLE \& MEANS, THE MODERN CORPORATION 1967, supra note 41 , at 75-84 (describing situations in which persons holding majority of shares do not exercise control over a corporation). 
domination ${ }^{333}$ can be seen as a parallel move. Corporate law understands this lack of symmetry between votes and control as a collective action problem, but additional factors such as false consciousness ${ }^{334}$ or the multiissue nature of voting ${ }^{335}$ may explain this feature of political life. For law to rely on nosecounting alone to identify who is vulnerable in society would be for law to fail to recognize the more subtle operation of power within and across groups.

\section{CONCLUSION}

"[M]en are described as I think they are," Adolf Berle writes of his work, "rather than as they think they are." shocked. The businessman will find that he is a politician and a commissar-perhaps even a revolutionary one. The liberal finds himself a traditionalist." 337 My juxtaposition of the corporate lawyer and the progressive activist may strike both as surprising and even uncomfortable. But corporate law has long been described as the constitutional law for the economic state. ${ }^{338}$ Both corporate law and constitutional law seek to order relations between heterogeneous persons who hold stakes in a shared enterprise. Yet the parallels between the two have rarely been fully drawn. In this paper, I have begun to sketch the unexplored but immanent connections in the two domains.

That the word "minority" is critical in both constitutional law and corporate law is not mere lexical coincidence. Much of life is affected by one's minority or nonminority status. On my reinterpretation, corporate law offers the same insight as critical scholarship: Law must take into account relations of domination and subordination. Corporate law already does this. Equal protection jurisprudence, at least as currently promulgated by the Supreme Court, denies it. But if there is to be a kind of grand unifying

333. See supra notes $210-211$ and accompanying text.

334. E.g., Tracy E. Higgins, Democracy and Feminism, 110 HARV. L. REV. 1657, 1665 (1997) (describing the social construction of a vision of good). But see ELY, supra note 185, at 165-67 (critiquing the suggestion that a "mistaken choice" should lead us to distrust majority judgment).

335. ELY, supra note 185 , at 164 (noting that voters are "typically confronted not with singleissue referenda but rather with packages of attitudes, packages we call candidates").

336. BERLE, supra note 197, at 3.

337. Id.; cf. BERLE, POWER, supra note 198, at 578 ("The modern corporation, oddly enough, is an unintended revolutionary instrument.").

338. See BERLE \& MEANS, THE MODERN CORPORATION 1932, supra note 41, at 357 ("The law of corporations ... might well be considered as a potential constitutional law for the new economic state ...."); Branson, supra note 241, at 621 ("Corporate law is like constitutional law with a small 'c.' ... Just as the Bill of Rights protects minorities from the tyranny of the majority, corporate law sets limits upon how far a majority may impose its will upon the minority."); Thompson, supra note 165 , at 1 ("In corporations, the most common collective entity in the private sphere, a parallel allocation [of power as in the public sphere] must be made. In this sense, corporate law is properly termed constitutional law."). 
theory of corporate and constitutional law, it will turn on this insight about power. 